Illinois State University

ISU ReD: Research and eData

Theses and Dissertations

7-3-2021

\title{
Incorporating Black Voices and Perspectives Into U.S. History Curricula Within Small, Rural Midwestern Schools
}

Jay Ryan Lawler Jr

Illinois State University, rlawler81@gmail.com

Follow this and additional works at: https://ir.library.illinoisstate.edu/etd

\section{Recommended Citation}

Lawler Jr, Jay Ryan, "Incorporating Black Voices and Perspectives Into U.S. History Curricula Within Small, Rural Midwestern Schools" (2021). Theses and Dissertations. 1449.

https://ir.library.illinoisstate.edu/etd/1449

This Thesis is brought to you for free and open access by ISU ReD: Research and eData. It has been accepted for inclusion in Theses and Dissertations by an authorized administrator of ISU ReD: Research and eData. For more information, please contact ISUReD@ilstu.edu. 


\title{
INCORPORATING BLACK VOICES AND PERSPECTIVES INTO U.S. HISTORY CURRICULA WITHIN SMALL, RURAL MIDWESTERN SCHOOLS
}

\author{
JAY R. LAWLER JR.
}

\section{Pages}

In the highly polarized American political climate, teachers are facing immense pressure from legislators, community members and administration that impacts their decisions regarding what and how to teach certain topics perceived as controversial. The purpose of this study was to determine the extent to which public high school teachers in small, rural Illinois schools incorporated Black voices and perspectives into their curricula to meet the requirements set out by the Illinois General Assembly in HB 0246. This study also aimed to understand what pedagogical methods are used when incorporating those voices and perspectives, along with the challenges that accompany teaching Black history. Participants for the study included US History teachers at small (100-500 students), rural, Illinois schools. The findings reveal that although educators approach teaching Black voices and perspectives in similar ways, the extent to which they teach them differs greatly. Teachers are impacted by political pressure from their communities, and this pressure in return impacts their curriculum choices. Teachers' choices varied by years of experience, gender and the extent to which teachers are willing to risk teaching topics perceived as controversial. The study has implications for advancing multicultural education within social studies curricula throughout the state, and will hopefully prompt decisive action from administrators, curriculum directors and teachers.

KEYWORDS: Black voices and perspectives, curricula, pedagogy, marginalized voices, teacher preparation 
INCORPORATING BLACK VOICES AND PERSPECTIVES INTO U.S. HISTORY

CURRICULA WITHIN SMALL, RURAL MIDWESTERN SCHOOLS

JAY R. LAWLER JR.

A Thesis Submitted in Partial

Fulfillment of the Requirements

for the Degree of

\section{MASTER OF SCIENCE}

School of Teaching and Learning

ILLINOIS STATE UNIVERSITY 
(C) 2021 Jay R. Lawler Jr. 
INCORPORATING BLACK VOICES AND PERSPECTIVES INTO U.S. HISTORY

CURRICULA WITHIN SMALL, RURAL MIDWESTERN SCHOOLS

JAY R. LAWLER JR.

COMMITTEE MEMBERS:

Robyn Seglem, Chair

May Jadallah

Benjamin R. Wellenreiter 


\section{ACKNOWLEDGMENTS}

My committee members, Robyn Seglem, May Jadallah and Benjamin Wellenreiter deserve many thanks for their continuous support throughout this semester-long process. I came into this process with little professional research background knowledge and a big idea, and their feedback and guidance guided me through. To the teachers who graciously volunteered their time after school, during a global pandemic, to speak with me candidly - thank you for your honestly, openness and commitment to bettering yourselves as teachers. I learned from each of you, and will be a better teacher for it. A special thanks to my wife, Brittany, for letting me sneak away to complete the writing of this thesis after the birth of our beautiful daughter, Lillian. We make a dynamic duo, and you have always supported me in all that I do.

J.R.L. 


\section{CONTENTS}

ACKNOWLEDGMENTS

CHAPTER I: INTRODUCTION 1

Problem Statement 3

Purpose of the Study $\quad 5$

$\begin{array}{ll}\text { Research Questions } & 6\end{array}$

$\begin{array}{ll}\text { Significance of the Study } & 6\end{array}$

CHAPTER II: LITERATURE REVIEW

Approaches to Multicultural Content Integration $\quad 8$

Mainstream Centric Curricula 11

$\begin{array}{ll}\text { Teacher Education } & 14\end{array}$

$\begin{array}{ll}\text { Conclusion } & 17\end{array}$

$\begin{array}{ll}\text { CHAPTER III: METHODOLOGY } & 18\end{array}$

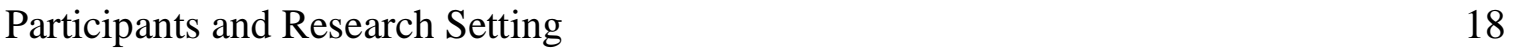

Qualitative Research Design 24

Data Collection Procedures 25

$\begin{array}{ll}\text { Data Analysis Procedures } & 27\end{array}$

$\begin{array}{ll}\text { Assumptions and Limitations } & 30\end{array}$

Ethical Considerations $\quad 30$ 
Banks and McGee-Banks' Levels of Integration

Contributions Approach

Ethnic Additive Approach

Transformative Approach

Pedagogical Strategies Used in Incorporation

Challenges Facing Participant Incorporation of Black Voices and Perspectives

Student-Level Challenges

District-Level Challenges

Community-Level Challenges

Impact of Introducing New Visions for Public Schools

First Impressions

Planned Teacher Use of New Visions

CHAPTER V: CONCLUSION, DISCUSSION AND RECOMMENDATIONS

Summary of Research Question Findings

When and Where Do We Find Stuff?

What They Taught Vs. How They Taught

Demographic Impacts

Gender and Its Role on Curriculum

Teacher Experience and Risk Taking

Political Climate's Impact on Curricular Decisions 
Suggestions for Future Research

Conclusion 


\section{CHAPTER I: INTRODUCTION}

The history of the United States is complex, diverse and packed with stories of struggle, victory, and compromise. The history of this country is inherently multicultural; however, oftentimes, the curriculum being taught in US History classrooms is not. Each state varies in their approach to teaching US History coursework. As of 2021, there are no national social studies standards to mandate what topics or historical figures students must learn about. Instead, development of standards typically falls within the state government sphere, leading to a complicated mix of historical viewpoints and interpretations. Dr. Tina Heafner, president of the National Council for the Social Studies, noted in an interview with $C B S$ News that "the process for adopting state standards, especially in a field like social studies that wrestles with the history of racism or white supremacy, can be politicized" (Duncan et al., 2020). As part of a two-monthlong investigation into how black history is taught in the U.S., CBS News investigators found that "seven states do not directly mention slavery in their state standards and eight states do not

mention the civil rights movement. Only two states mention white supremacy, while 16 states list states' rights as a cause of the Civil War" (Duncan et al., 2020).

State social studies standards detail what public school students are expected to know in specific states. States typically create standards following one of two methods: content-based or skill-based standards. Some states, such as Michigan, base their state US History standards on the content itself. For example, Michigan's US History standards are based on 7 different historical eras. Standard 6.2.2 is as follows: "World War I - explain the causes of World War I, the reasons for American neutrality and eventual entry into the war, and America's role in shaping the course of the war" (Michigan K-12 Standards, 2019, p.110). States like Illinois focus on skill-based standards similar to the language found in the national Common Core State 
Standards (yet only 41 states have joined), and the National Council for the Social Studies' C3 Standards. Illinois Standard SS.H.8.9-12 is as follows: "Analyze key historical events and contributions of individuals through a variety of perspectives, including those of historically underrepresented groups" (Illinois Social Science Standards, 2017). However, even though Illinois does not prescribe required historical content in their standards, the Illinois General Assembly, through legislation, aims to define required multicultural content in US History curricula throughout the state. As indicated in 105 ILCS 5/27-21: "The teaching of history shall include a study of the role and contributions of African Americans and other ethnic groups including but not restricted to Polish, Lithuanian, German, Hungarian, Irish, Bohemian, Russian, Albanian, Italian, Czech, Slovak, French, Scots, Hispanics, Asian Americans, etc., in the history of this country and this State" (from Ch. 122, par. 21-27). Revisions to these mandates continue to change with the times. In 2019, the Illinois General Assembly added to those broad mandates, now requiring the inclusion of LGBTQ+ history in US History curricula. That same statute mentioned above also mandates that textbooks purchased using state issued funds be "secular, non-religious, and non-sectarian, and non-discriminatory as to any of the characteristics under the Illinois Human Rights Act. Textbooks authorized to be purchased under this Section must include the roles and contributions of all people protected under the Illinois Human Rights Act" (Sec. 2-3.155.).

At the time of writing, the Joint Committee on Administrative Rules approved the incorporation of "culturally responsive teaching and leading standards" to be incorporated in all Illinois teacher preparation programs, taking effect in 2025. According to the amendment itself, these standards aim to prepare teachers and leaders to be "reflective and gain a deeper understanding of themselves and how they impact others, leading to more cohesive and 
productive student development as it relates to academic and social-emotional development for all students" (Sec. 24.50a). This move was inherently controversial amongst the public and divisively partisan in Springfield, with all 6 Republican committee members voting to suspend the rule, and all 6 Democrats voting yes. Although the new Illinois State Social Studies Standards are no longer content-based, clearly, the state has broadly defined that US History and now school curricula overall be multicultural and inclusive of many ethnic and cultural groups.

\section{Problem Statement}

The public nature of George Floyd's murder in the Spring of 2020 sent shockwaves throughout the entire world. The event left many educators questioning the curriculum they had worked so diligently to create. How could the image of an unarmed man being pinned to the ground so eerily reminiscent of those seen throughout Reconstruction and the Civil Rights Movement still be possible? The aftermath of his death left many feeling angry, hateful, confused and even unsure of how this violence was still possible over fifty years after Black leaders such as Martin Luther King Jr., Malcolm X, and Fred Hampton were killed for fighting many of the same injustices. His death left some social studies educators thinking about their adherence to a "single story," as Chiamanda Adichie mentions in her 2009 TED Talk titled "The Danger of a Single Story." By adhering to a curriculum perpetuating the single story, educators fail to truly embrace a multicultural approach to the subject that arguably needs it the most: US History. Adichie (2009) says in her TED Talk (13:11-13:21) that "the single story creates stereotypes, and the problem with stereotypes is not that they are untrue, but that they are incomplete." By building a curriculum based on a single mainstream-centric story, educators tell an incomplete, biased version of history. Floyd's death has been twofold for the social studies: curricular conversations surrounding U.S. history have become more inclusive, empathetic and 
engaging as a result; however, outside commentators from the political "Far Right" have accused America's public educators of being indoctrinators of Critical Race Theory. It provided the spark necessary for revamping my own curriculum, one I once believed to be inclusive. Students deserve to hear multiple stories, and oftentimes, they crave them. Educators must take on the challenge of striving to become better multicultural educators and this study is one step in that process. If a goal of the social studies teacher is to prepare their students to be active, engaged citizens, then our teachings must prepare them for a diverse world.

Many states, including Illinois, clearly mandate that US History curricula be multicultural and inclusive. Banks et al. (2001) have defined multicultural education as "an idea, an educational reform and a process that seeks to create equal educational opportunities for all students including those from different racial, ethnic and socio-class groups and that strive to change and restructure the total school environment." Although many states clearly mandate that US History curricula be multicultural and inclusive of various ethnic and cultural groups, US History students throughout the United States have not necessarily always received a multicultural history education. Gollnick (1995), in a sweeping 1993 survey, found that only 14 states expected local schools to include multicultural content in their curriculums while four other states required cultural diversity content. Additional literature on state multicultural education policies include Mitchell and Salisbury (2000), which examined the current state of policies via a survey administered in 1998. This survey attempted to build upon Gollnick's (1995) work while providing historical background for each state. Their study (as cited in Kellogg, 2015) found that "unfortunately, some of the survey responses either lacked sufficient detail or were incomplete and were therefore unable to verify the accuracy of the results reported" (p. 12). 
Zoë Padrón, a teacher from Charlottesville, Virginia, the location of the infamous and bloody 2017 "Unite the Right" rally, echoes this frustration of lacking multicultural standards in her current work redeveloping multicultural, inquiry-driven curricula for US History educators in that state: "We're teaching kids an actual narrative of things that have happened that are true, that are facts, that they otherwise might not learn because it's not included in the Standards of Learning, because it's not included in textbooks, because it's not part of the narrative norm" (Knott, 2020). To complicate matters, teachers are constantly being pulled in two competing directions: to remain neutral on controversial, and political topics, yet also teaching those mandated, and often highly politicized topics. Recent research by Dunn, Sondel and Baggett (2019) supports this, concluding many teachers continue to feel pressured to remain neutral when discussing former President Trump and are generally uncomfortable addressing racial and social justice issues in the classroom.

\section{Purpose of the Study}

Past literature is lacking in terms of analyzing specific, small-town schools and their integration of diverse perspectives into history curricula during this time of highly polarized politics in America. This study aimed to uncover how teachers navigate those competing directives and do their diligence in telling the story of American history. The purpose of this study was to analyze the extent to which small, rural Midwestern educators integrate Black voices and perspectives into their history curricula, along with their pedagogical approaches to teaching this content. The study seeks to understand both what teachers are teaching (content) and how teachers teach that content (pedagogy).

Unfortunately, available literature concerning multicultural education within rural schools is dated. Ayalon (1993), in a national study of 50 state departments of public instruction 
found that personnel from all-White school districts did not view multicultural education as important. Similarly, Yeo (1999) found rural school administrators indifferent to multicultural education due to the absence of diversity in their student populations while some research links school size with principals' perceived support for multicultural education. This study, given the current socio-political climate, aimed to generate more recent literature concerning small school approaches to incorporating multicultural content into history classes.

\section{Research Questions}

The following research questions will be addressed in this study:

1. To what extent do teachers teach history through historically marginalized perspectives, specifically through Black voices and perspectives?

1. What instructional methods are being used to teach these voices and perspectives?

2. What challenges do teachers face in incorporating Black voices and perspectives into their curricula?

3. What impact, if any, do multicultural teacher resources have on an educator's restructuring or reshaping of their own history curriculum?

\section{Significance of the Study}

The need for a multicultural education, especially in social studies, is more important now than ever. The racial injustice and social justice protests of 2020 show that young people are demanding change, and that change needs to start in the classroom. Those conversations need to start in the classroom. This study is meant to inform teachers and administrators on the need to rethink curricula to incorporate non-Eurocentric approaches to teaching US History. Incorporating diverse perspectives into the history curriculum encourages not just critical 
thinking and historical thinking skills, but also understanding and empathy, both of which are lacking in the public sphere today. 


\section{CHAPTER II: LITERATURE REVIEW}

This chapter outlines literature relevant to the purpose of this study. The chapter is divided into three sections: approaches to multicultural content integration, mainstream centric curriculums and issues surrounding teacher preparation.

\section{Approaches to Multicultural Content Integration}

Various approaches to multicultural education reforms have been developed since the 1960s, including the contributions, ethnic additive and transformative approaches (Banks \& McGee-Banks, 2016). As more states like Illinois move away from content-based standards, and instead transition to skill-based standards similar to the Common Core and the National Council for the Social Studies' C3 Standards, the need to incorporate diverse perspectives has never been stronger or more necessary. According to Banks and McGee-Banks (2016), the contributions approach is "characterized by the insertion of ethnic heroes/heroines and discrete cultural artifacts into the curriculum" (p.155). This approach typically involves basic level integration, and fails to challenge the mainstream curriculum. An example of this approach would be to set aside a day to study Martin Luther King Jr. on his birthday.

Banks and McGee-Banks (2016), note the ethnic additive approach "allows the teacher to put ethnic content into the curriculum without restructuring it" (p.158). This is the first step in moving towards a more representative curriculum, and is often accomplished by inserting book studies or films within current units. Epstein's (2000) research concerning this approach is quite revealing. He surveyed both white and black students in a history class utilizing different approaches to teaching history. His data concludes that students constructed different

perspectives concerning racial history, and that "African Americans' historical experiences were 
only taught during lessons related to enslavement, the Civil Rights Movement, and as they related to white people's historical experiences" (p. 204).

Banks and McGee-Banks (2016) define the transformative approach as one that "changes the basic assumptions of the curriculum and enables students to view concepts, issues, themes and problems from several ethnic perspectives and points of view" (p. 159). The mainstream perspective is only one of several perspectives being analyzed in this approach.

Ultimately, as Banks and McGee-Banks (2016) note, the social action approach is the ultimate end goal for educators, which involves "students not only being instructed to understand and question social issues, but to also do something important about it" (p. 161). However, reaching this level of integration does require a great deal of training, experience and support from administrators and the community. Each of the four integration approaches is summarized in Table 1 below:

\section{Table 1}

Adapted From Banks and McGee-Banks' (2016) Multicultural Integration Approaches

\begin{tabular}{|c|c|}
\hline $\begin{array}{c}\text { Integration } \\
\text { Approach }\end{array}$ & Example \\
\hline Contributions & $\begin{array}{c}\text { Teaching the "heroes and holidays" of Black history; randomly inserted into } \\
\text { curriculum }\end{array}$ \\
\hline Ethnic Additive & $\begin{array}{c}\text { Incorporating John Lewis' March graphic novel set into a unit on the Civil } \\
\text { Rights Unit }\end{array}$ \\
\hline Transformative & Entire curriculum is reshaped to study various ethnic viewpoints \\
\hline Social Justice & Students take action on their learning to extend outside of the classroom \\
\hline
\end{tabular}

Along with these approaches to content integration, Sonia Nieto (2008) provides a spectrum model for levels of support in teaching multicultural education: tolerance, acceptance, respect and affirmation, solidarity and critique - this model is dynamic, penetrable and schools 
may even use a combination of the levels. This model provides a spectrum with which teachers and schools can move toward deeper, more impactful curricular integration. A tolerant school, according to Nieto, endures cultural differences, but fails to embrace them. A tolerant curriculum would encourage assimilation, and even perpetuate the stereotypical idea of the traditional American Dream. An accepting school accepts cultural differences, and does not disparage them. A respectful school admires diversity, and uses it as the basis for change within school functions. This correlates nicely with the transformative approach mentioned above. Lastly, an affirmative school realizes the challenges associated with cultural differences can act as opportunities for learning, and students can work together to solve problems. The ultimate goal, according to Nieto (2008) is that "the many differences that students and their families represent are embraced and accepted as legitimate vehicles for learning" (p. 26).

Whether using Banks and McGee-Banks' approaches or Nieto's levels, Gholdy Muhammed created a framework to help teachers move along the multicultural integration spectrum. In her work Cultivating Genius, Muhammad (2021) presents a framework called Historically Responsive Literacy, which is "centered on the literacy theories of Black people and a practical framework that teachers can use to guide and shape instruction" (p. 48). Muhammad provides five actionable steps teachers can take to responsibly integrate multicultural content into the classroom. These are summarized below:

1. Listen to and trust the child. Teachers should actively consult with their students of color to better understand them and their learning needs.

2. Engage in teacher research. Teachers should be reflective learners and thinkers about their own pedagogy and students. 
3. Ask students to write their autobiographies and personal narratives. Not only is this a great way to study personal history, but students are then given a voice in the classroom.

4. Interview parents or family members of students who are culturally different from them. Teachers should encourage parent and community relationships to extend learning beyond the classroom.

5. Study the curriculum and explore ways to make studies meaningful to students and their families and communities. By perpetuating a mainstream-centric curriculum, teachers passively follow curriculum and standards, and students fail to receive a proper and inclusive social studies education.

Even assessment can be negatively impacted by a lack of content integration. Popham (2014) identifies attitudinal targets for teacher instruction and affective assessments with one being "appropriate attitudes towards those who differ from us" (p. 254). Popham continues saying "the more tolerant and accepting students are towards members of other ethnic, gender, national, racial, or religious groups, the more likely those students will behave properly towards such individuals in the future" (p. 254).

\section{Mainstream-Centric Curricula}

Collins and O’Brien (2011) define a mainstream-centric curriculum as one that "presents information and concepts from the point of view of the dominant social class" (p. 280). The dominant view is typically that of an Anglo-Saxon, or Eurocentric perspective. For far too long, and arguably still, a Eurocentric approach to history was the common approach to teaching US History. Django Paris, in his work with Culturally Sustaining Pedagogy, assesses the history and goals of a mainstream-centric schooling system. Paris (2012) states: 
The dominant language, literacy, and cultural practices demanded by school fell in line with White, middle-class norms and positioned languages and literacies that fell outside those norms as less-than and unworthy of a place in U.S. schools and society. Simply put, the goal of deficit approaches was to eradicate the linguistic, literate, and cultural practices many students of color brought from their homes and communities and to replace them with what were viewed as superior practices. (p. 93)

This biased approach is only supportive of developing the identity of White learners as curricular narratives cater to the dominant culture (Busey \& Russell, 2016). However, a recent study conducted by Jimenez et al. (2017) suggest a growing inclusion of marginalized content into social studies textbooks from around the globe. Their study found that social science textbook coverage of topics such as human rights, global citizenship, gender equality, and multiculturalism and social diversity have, in general, steadily increased since the middle of the 20th century. Regardless of this, Banks and McGee-Banks (2016) note that political and ideological resistance to multicultural curricula still exists, as these typically challenge existing power structures in the US. To challenge these power structures, it is important for students to "encounter the other," as Cohen (2008) noted and implemented in her own classroom. By having her students read autobiographical essays from people of diverse backgrounds, Cohen's intention was for students "to imagine the lives of people different from them (by virtue of sexual orientation, religion, ethnicity, race, or class) to enable them to understand not only the insidious effects of oppressive dynamics but also to realize the sources of strength that exist within every group whose story has been suppressed" (p. 61). On the other hand, teaching through the "other's experience" can be difficult, and trying, as Prentice Chandler once experienced in his own rural, north Alabama American History classroom. Chandler (2006) was "attacked" by the community, 
yet learned valuable lessons when planning his curriculum through marginalized groups including "demanding that my school system protect me and what I was trying to do" (p. 357). In Chandler's case, his district did in fact support him after realizing he was following local, state and national standards, yet not all educators may receive this same support. Chandler then studied two social studies educators from that same rural, north Alabama region three years later. In interviewing one teacher, Chandler (2009) found both educators seemed to view teaching about race as being "forced and outside the accepted norm of pedagogy for his classes" (p. 267).

The impact of a strictly mainstream-centric curriculum on minority students is well known. Data compiled by Harris and Clarke (2011) reveals that among British students, "history did not feature in any pupils' list of favorites but was cited quite frequently as a least favorite subject amongst those from minority ethnic backgrounds" (p. 161). Gholdy Muhammad, in her historically responsive literacy framework, stresses the importance of student representation within curriculums, before skill or content learning. Muhammad (2021) states that "before getting to literacy skill development such as decoding, fluency, comprehension, writing or any other content-learning standards, students must authentically see themselves in the learning" ( $p$. 69). A mainstream-centric US History curriculum generally portrays only a narrow perspective, that of White Americans, and it is typically not even an authentic representation in itself.

The effects of a mainstream-centric curriculum extend past just the history classroom. Dating back to 2009, the Civic Mission of Schools reports a civic engagement gap between minority and lower SES families and affluent and white families. Kahne (2009) notes that this gap was caused by fewer civic learning opportunities for low-income students and minority students, which included discussing current events, studying issues of concern to students, facilitating open classroom discussions of social and political issues, studying related social 
sciences, interacting with civic role models, participating in extracurricular activities, service learning, and simulations. The perpetuation of mainstream-centric curriculums not only endangers educational achievement for all students, but also poses a risk to students' future civic engagement as well. Lastly, a $21^{\text {st }}$ century educator cannot adhere to a mainstream curriculum because it inhibits risk taking by students, and fails to challenge students to think critically about the world in which they live.

\section{Teacher Education}

Milner (2009) argues that teacher educators from different educational institutions across the country need to come together and focus on building a diversity studies curriculum for teacher education. Milner asserts that teachers and teacher educators need to be mindful of five fundamental concepts critical to teacher education: color-blindness, cultural conflict, myth of meritocracy, deficit conceptions, and expectations (Milner, 2009). When teachers enter teacher education programs, their ways of thinking and mindset ultimately impact curricular decisionmaking, therefore, by critically assessing and incorporating those five concepts into teacher preparation programs, a “common curriculum” approach emerges. Although educators understand the need to incorporate diverse perspectives, Alexander and Weekes-Bernard (2017) note the lacking training of both pre-service and veteran teachers which also presents issues for the integration of multicultural education. One of these issues involves postsecondary faculty members preparing preservice educators. Sciame-Giesecke, Roden and Parkison (2009) conducted a five-year survey to shed light on how faculty members (members of the nursing and business departments) at a small regional college were implementing multicultural course transformation in their classrooms to prepare students to live and work in a diverse world. Their data revealed that although a vast majority (90\%) of faculty added multicultural content to their 
class, only $18 \%$ of the faculty surveyed reflected on student diversity issues in their classes. This small minority (18\%) of teachers also felt they better understood their students' backgrounds and lived experiences by incorporating multicultural content into their curriculums. In their discussion of the data, Sciame-Giesecke, Roden and Parkison (2009) state that "perhaps this is because, in higher education, understanding who our students are is clearly not something that most faculty have been trained to do, nor are they comfortable in doing this type of analysis" (p. 163). Harris and Clarke (2011) extensively studied preservice educators and the challenges associated with teaching a multicultural curriculum. Most pressing was a lack of experience with prior diverse settings, as "the majority of trainees had had little prior experience of diverse settings; their schooling, university study and employment opportunities were overwhelmingly confined to white, monocultural settings" (p. 165). Groenke et al. (2015) also note the impact this lack of experience has on minority adolescents stating that "nearly 85 percent of all secondary teachers are white, monolingual native English speakers, many of whom have had little, if any, training in working with culturally and linguistically diverse learners; many of whom benefit from white privilege; and many of whom hold deficit-oriented beliefs toward young people of color" (p. 37).

Richard Neumann, an education professor at San Diego State University, examined course requirements for elementary and secondary level teacher preparation programs at 302 American universities. Neumann (2010) found that among programs that train students to work as elementary school teachers, $45 \%$ required at least one course in multicultural education. For programs that train secondary school teachers, $45 \%$ required students to complete at least one multicultural education course. Neumann learned that a larger percentage of public university programs required a multicultural education course than did programs offered at private 
universities. However, one overarching multicultural course is not enough, as Washington and Humphries (2011) note. They studied the impact this lack of preparation had on social studies teachers wanting to discuss controversial issues, specifically those including race in the classroom. They note that one young social studies teacher's approach to discussing controversial issues surrounding race went as follows:

While she had some success in facilitating such discussions, she also had to navigate difficult situations in which she could not call on any formal training. Teacher preparation programs can do much to help prevent these "trial by fire" classroom scenarios by offering methods courses that allow students to explore the teaching of controversial issues through readings, case study analysis, and modeling, and by asking preservice teachers to write teaching philosophies that include statements on this important part of the curriculum. (p. 110)

Clearly, lacking experience in teacher preparation programs and professional development leads to an adherence to a mainstream-centric curriculum because it is common, and familiar. This adherence restricts or diminishes students' exposure to different perspectives, opportunities to facilitate meaningful discussions, and occasions for historical thinking skills to be applied. Warren (2005) notes that "schools cannot teach children well if teachers lack an understanding of their students' cultures and lives, and if they lack meaningful relationships with their families" (p. 134). Ken Zeichner and Lorena Guillen (2018) further explore this lack of community involvement by studying the experiences of a group of nine community-based mentors of teacher candidates over the course of several years. Their study finds that the connections between community-based mentors and teacher candidates "often resulted not only in the beginnings of relationships but also in possible resources, supportive places, and 
introductions to communities that then might become their partners in their future classrooms" (p. 151). Clearly, community involvement enriches the curriculum, authentic learning experiences of the students and the community itself.

\section{Conclusion}

Schools and educators most likely do not fall into one integration level or approach, and probably combine various approaches when creating curriculum. These various frameworks for infusing multicultural content into curricula are not new, yet we see that preservice, new and even veteran teachers still do not feel prepared to adequately incorporate it, or reflect on student diversity issues. When this lack of preparation occurs, teachers simply "teach what they know," and abandon community members along the way, leading to a perpetuation of the mainstream centric curriculum. What remains to be answered revolves around the inclusion, or lack of inclusion of specific multicultural content: Black voices and perspectives into the social studies curriculum. In a time where America is heavily divided amongst racial lines, what factors discourage educators from incorporating this content into the curriculum? What impact does the setting of their school have on their incorporation? This study aims to answer these questions by assessing the challenges teachers in small, rural schools face when trying to incorporate Black voices and perspectives into the curriculum. 


\section{CHAPTER III: METHODOLOGY}

This study aims to assess how teachers from small, rural school settings incorporate Black voices and perspectives into their curriculum. The research will answer the following questions:

1. To what extent do teachers teach history through historically marginalized perspectives, specifically through Black voices and perspectives?

1. What instructional methods are being used to teach these voices and perspectives?

2. What challenges do teachers face in incorporating Black voices and perspectives into their curricula?

3. What impact, if any, do multicultural teacher resources have on an educator's restructuring or reshaping of their own history curriculum?

This chapter outlines the study design, and introduces the research participants and methods used to collect and analyze data.

\section{Participants and Research Setting}

As Miles and Huberman (1994) note, in qualitative studies, researchers frequently work with small samples of participants who are studied intensely and in depth. This study was conducted among four small, rural midwestern schools. The researcher focused on a conference of thirteen different school districts in Illinois. The participants were high school social studies teachers from four of the thirteen schools. Participant schools were selected based on Flick's (2007) assertions that "sampling is oriented on specific criteria" (p. 88). For this study, one criterion was applied: the town's voting record in the 2020 presidential election. This criterion was selected to represent political challenges teachers in small, rural settings often face when teaching history through the perspective of marginalized voices, including African Americans. 
The town's political leanings could ultimately impact curriculum choices. According to a 2018 study conducted by UCLA's Teaching and Learning in the Age of Trump research team, which surveyed over 1,500 teachers from across the United States, it was found that there are three primary ways in which the national political environment negatively affects high school students: heightened student stress about their own well-being and that of their families, polarized and contentious classroom environments, and rhetoric targeting vulnerable students. The study even concluded that "a growing number of schools, particularly predominantly White schools, became hostile environments for racial and religious minorities and other vulnerable groups" (p. VI).

A 2020 study, from members of the same research team, titled School and Society in the Age of Trump, which interviewed 500 principals from around the United States, found that nearly nine out of ten principals reported incivility and contentiousness in the broader political environment has "considerably affected their school community" (p.1). Some of those effects included "contentious behavior in classrooms, hostile exchanges outside of class, and disagreements among community and staff that negatively impacted the school” (p.1). Based on those findings, the researcher chose to study the relative extremes of the political spectrum within the conference to assess whether or not the town's political learnings could possibly sway the integration of Black voices and perspectives into the school's curriculum. Therefore, the two schools' towns with the highest vote totals (by percentage) for Joseph Biden, and the two schools' towns with the highest vote totals (by percentage) for Donald Trump, were purposefully selected as follows:

- (Town C) voted most liberal (37\% for Biden, 63\% Trump).

- (Town K) voted 2nd most liberal (33\% for Biden, 67\% Trump).

- (Town H) voted most conservative (80\% for Trump, 20\% Biden) 
- $\quad$ (Town M) voted $2^{\text {nd }}$ most conservative (76\% for Trump, $24 \%$ Biden)

To clarify, the relative extremes in this study still include highly conservative towns. Even though two towns were deemed "most liberal," all thirteen towns within the conference overwhelming voted Republican. The most liberal town schools were selected based on percentages; however, the following school participants declined an invitation to join the study: Town C and Town K. Both participants declined due to an "overload" of current assignments, including extra-curricular coaching duties. Town $\mathrm{C}$ was replaced with Town A. Town $\mathrm{K}$ was replaced with Town F to start, but Town F's participant also declined due to an abundance of duties at the time. The researcher then moved to replace Town $\mathrm{K}$ with Town E.

Voting, racial and ethnic and school population data for all thirteen conference schools is provided below for context:

\section{Table 2}

Breakdown of Racial, Ethnic and School Population Data for Small-School Conference

\begin{tabular}{|c|c|c|c|c|c|c|c|}
\hline $\begin{array}{l}\text { Town } \\
\text { Name }\end{array}$ & $\begin{array}{c}\text { Democratic } \\
\text { Vote \% } \\
\text { (Biden) }\end{array}$ & $\begin{array}{c}\text { Republican } \\
\text { Vote } \% \\
\text { (Trump) }\end{array}$ & $\begin{array}{c}\text { White } \\
\text { Student \% }\end{array}$ & $\begin{array}{c}\text { Black } \\
\text { Student \% }\end{array}$ & $\begin{array}{l}\text { Hispanic } \\
\text { Student \% }\end{array}$ & $\begin{array}{c}\text { Asian } \\
\text { Student \% }\end{array}$ & $\begin{array}{c}\text { Two or More } \\
\text { Race Student \% }\end{array}$ \\
\hline Town A & 33 & 67 & 92.7 & 0.8 & 2 & 0.8 & 3.8 \\
\hline Town B & 25 & 75 & 88.7 & 1.7 & 5 & 0 & 4.2 \\
\hline Town C & 37 & 63 & 95.4 & 1 & 1.4 & 0.1 & 2 \\
\hline Town D & 25 & 75 & 96.1 & 0.5 & 1.1 & 0.1 & 1.7 \\
\hline Town E & 30 & 70 & 93.2 & 0.6 & 3.6 & 0.6 & 1.9 \\
\hline Town F & 30 & 70 & 86.4 & 1.9 & 8.5 & 0.3 & 2.5 \\
\hline Town G & 25 & 75 & 94 & 1.1 & 0.4 & N/A & 4.5 \\
\hline Town $\mathrm{H}$ & 20 & 80 & 89.1 & 2.2 & 5.1 & 1.4 & 2.2 \\
\hline Town I & 30 & 70 & 91.6 & N/A & 2.7 & 0.7 & 5 \\
\hline Town J & 32 & 68 & 90.8 & 0.5 & 3.8 & 0.8 & 3.8 \\
\hline
\end{tabular}




\begin{tabular}{|l|c|c|c|c|c|c|c|}
\hline Town K & 33 & 67 & 92.9 & 2.1 & 0.7 & N/A & 3.5 \\
\hline Town L & 25 & 75 & 88.8 & 1.2 & 7.6 & N/A & 2.4 \\
\hline Town M & 24 & 76 & 90.2 & 2.5 & 4.2 & 1.4 & 1.7 \\
\hline Averages & $\mathbf{2 8 . 3 8 \%}$ & $\mathbf{7 1 . 6 2 \%}$ & $\mathbf{9 1 . 5 3 \%}$ & $\mathbf{1 . 2 4 \%}$ & $\mathbf{3 . 5 5 \%}$ & $\mathbf{0 . 4 8 \%}$ & $\mathbf{3 . 0 2 \%}$ \\
\hline
\end{tabular}

Voting data courtesy of illinoiselectiondata.com/analysis/precinct. Racial/ethnic diversity \& population data courtesy of Illinois School Report Cards.

What follows is a brief description of each participant teacher, along with their current US History units or themes and the inclusion of Black voices and perspectives. Participant names have been replaced with the letter of the town they teach in to protect anonymity.

1. Teacher $\mathrm{H}$ has 5-10 years of experience teaching social studies at a small, rural high school. H is a male teacher who holds a Bachelor's degree in History Social Science Education and a minor in Psychology. $\mathrm{H}$ has taught 7 th-12th level courses in various different social studies courses including both World and American History, government, and global issues courses. Teacher $\mathrm{H}$ teaches a non-Advanced Placement American History course which covers the Revolutionary War through World War II. This course is framed around eleven different units, and the following table reveals whether or not Black voices and perspectives are included in the unit in any way:

\section{Table 3}

Teacher H's Current Unit Structure and Inclusion of Black Voices and Perspectives

\begin{tabular}{|c|c|}
\hline Unit & Black Voices/Perspectives? \\
\hline American Revolution & Yes \\
\hline Nation Building & No \\
\hline American West \& Age of Jackson & Yes \\
\hline Civil War & Yes \\
\hline Reconstruction & Yes \\
\hline Gilded Age \& Progressive Era &
\end{tabular}




\begin{tabular}{|c|l|}
\hline American Imperialism & No \\
\hline WW1 & Yes \\
\hline The 20s \& 30s & Yes \\
\hline WW2 & No \\
\hline
\end{tabular}

2. Teacher A has 1-4 years of experience teaching social studies at a small, rural high school. A is a male teacher who holds a Bachelor's degree in History and Secondary Education. A has taught sophomore-senior level courses in social studies including government, sociology, psychology, and American History. Teacher A teaches an Advanced Placement American History course which covers the arrival of Christopher Columbus through World War II and "modern times." This course is framed around nine different units, and the following table reveals whether or not Black voices and perspectives are included in the unit in any way:

\section{Table 4}

Teacher A's Current Unit Structure and Inclusion of Black Voices and Perspectives

\begin{tabular}{|c|c|}
\hline Unit & Black Voices/Perspectives? \\
\hline Columbus: Prior Through Contact & No \\
\hline Early Colonial & No \\
\hline Colonial America & Yes \\
\hline The Nation Takes Shape (Revolution) & No \\
\hline Jackson Years & No \\
\hline The Civil War \& Reconstruction & No \\
\hline Industry \& The Gilded Age & No \\
\hline Imperialism \& Progressive Era & Yes \\
\hline WWw2 \& Modern Times & Yes \\
\hline
\end{tabular}


3. Teacher $\mathrm{M}$ has 5-10 years of experience teaching social studies at a small, rural high school. M is a female teacher who holds a Bachelor's degree in History and Secondary Education, as well as a Master's degree in Educational Administration. M has taught various social studies courses including both American and world history, government, global and cultural issues courses, and sociology. Teacher M teaches a regular American history course which covers the arrival of Columbus through the 1960s and 1970s. This course is framed around twelve different units, and the following table reveals whether or not Black voices and perspectives were included in the unit in any way. The last two units, Cold War and the 60s and 70s, were not taught during the 2020-2021 school year and are in planning.

\section{Table 5}

Teacher M's Current Unit Structure and Inclusion of Black Voices and Perspectives

\begin{tabular}{|c|c|}
\hline Unit & Black Voices/Perspectives? \\
\hline First Americans \& Columbus & Yes \\
\hline Early Colonies \& Independence & Yes \\
\hline Building a Nation & No \\
\hline National Expansion \& Reform (1800-1850) & Yes \\
\hline The Civil War \& Perpetuating Slavery & Yes \\
\hline Reconstruction: Progress \& Pushback & Yes \\
\hline Industry \& Progress & No \\
\hline WW1 & Yes \\
\hline $20 s \& 30 s$ & No \\
\hline WW2 & TBD \\
\hline Cold War & TBD \\
\hline The 60s \& 70s & \\
\hline
\end{tabular}


4. Teacher E has 10+ years of experience teaching social studies at a small, rural high school. E is a female teacher who holds a Bachelor's degree in English Education and has a History Education minor; MS in History with Post Graduate work in American History and Global Studies. E has taught various social studies courses including global issues courses, and both American and world history courses. Teacher E teaches a dual credit American experience course which covers early America through World War Two. This course is framed around five different themes, and the following table reveals whether or not Black voices and perspectives were included in the unit in any way. E's themes are framed around ages.

\section{Table 6}

Teacher E's Current Thematic Structure and Inclusion of Black Voices and Perspectives

\begin{tabular}{|c|c|}
\hline Unit & Black Voices/Perspectives? \\
\hline Age of Faith & Yes \\
\hline Age of Reason & Yes \\
\hline Age of Optimism & Yes \\
\hline Age of Actuality & Yes \\
\hline Age of Diffusion & Yes \\
\hline
\end{tabular}

\section{Qualitative Research Design}

The research questions were studied using a qualitative approach. The researcher sought to present trends concerning the incorporation of Black voices and perspectives within the history curricula among small schools. Maxwell (2013) advocated that qualitative research works with the universe of meanings, motives, aspirations, beliefs, values and attitudes, which corresponds to a deeper space of relationships, processes and phenomena that cannot be reduced to the operationalization of variables. Since the researcher was concerned with attitudes and motives revolving around the incorporation of Black voices and perspectives, the in-depth 
thought processes of the participants were best contextualized and described through qualitative means.

\section{Data Collection Procedures}

The researcher utilized data collected through a three-step combined interview, or indepth interview process. Queirós et al. (2017) note that "in-depth interviews provide very rich information and it offers the opportunity to ask follow-up questions, probe additional information, justify previous answers, and establish a connection between several topics" (p. 378). The interview questions were created by the researcher, and aimed to uncover participants' current practices as they relate to the current inclusion of Black voices and perspectives in their history curriculum. Queirós et al. (2017) note that a variant of the in-depth interview, known as a semi-structured interview, is one "in which there is a set of predefined questions, but in which freedom is given to explore one of the questions in greater depth" (p. 378). The interviews included open-ended questions, with potential for various follow up questions to be asked. To test the authenticity of the interview questions, the researcher interviewed his social studies colleague at his own school, and conducted a test interview with a member of his thesis committee, who has over ten years' experience in the social studies classroom.

Flick (2007) describes combined interviews as those with narrative parts (eg., telling a story) and question-answer parts. This three-step process was selected based on Roberts' (2013) study of satisfaction levels of rural teachers in Australia, where he utilized a semi-structured interview design documenting that interviews allow greater depth and the development of rich narratives (as cited in Minichiello et al., 1990).

The first interview aimed to assess each educator's current integration of Black voices and perspectives into their curriculums. The second interview revolved around a teaching artifact 
showcasing the interviewee's integration of Black voices and perspectives into their current curriculum. At the end of the second interview, the researcher introduced the educator to view and analyze resources from New Visions for Public Schools (NY) in order to revise, update or reshape entirely their integration of Black voices in their curriculum. New Visions for Public Schools (2021) website describes how their social studies curriculum is designed:

The curriculum integrates rich primary and secondary texts, maps, images, videos, and other reputable online sources into materials that meet the New York State K-12 Social Studies Framework's objectives and provide students an opportunity to improve literacy skills by focusing on thinking critically while reading, writing, and speaking like historians. (para. 2)

New Visions was selected from a field of various reputable teacher resources due to the profound impact it had on the researcher's own curriculum, specifically New Visions' Reconstruction unit. The final interview aimed to uncover the impact those resources had on the educators' own curriculum choices and pedagogical techniques.

This three-step combined interview process is grounded in phenomenology. According to Neubauer et al. (2019), "phenomenology can be defined as an approach to research that seeks to describe the essence of a phenomenon by exploring it from the perspective of those who have experienced it" (p. 91). The combined interview process reveals authentic lived experiences by current teachers in the field, providing an ample narrative set of data. Teherani et al. (2015) note that "the goal of phenomenology is to describe the meaning of this experience- both in terms of what was experienced and how it was experienced" (as cited in Neubauer et al., 2019, p. 91). 
The researcher utilized video conferencing software (Google Meet) to interview four educators. The participant interviews were conducted via Google Meet, and the interviews were transcribed using the Google Chrome add-on "Meet Transcript."

\section{Data Analysis Procedures}

A significant amount of data, which consisted of interviews and researcher notes was collected and then analyzed for this study. In qualitative research, the researcher interprets the data, provides description of the results, and draws conclusions. Creswell (2013) describe data analysis in qualitative research to consist of preparing and organizing data, reducing data into themes through the process of coding and condensing the codes, and then representing data in figures, tables, or a discussion. Creswell (2013) describes the first step of the process to involve reading and memoing. Creswell suggests the researcher begins by getting a sense of the whole database of information, which would include reading the transcripts in their entirety several times and writing notes or memos in the margins of notes and transcripts. During live interviews, the researcher wrote notes and observations and then compared those notes to the transcript at least two different times. From these notes and observations came codes. According to Saldaña (2015), "coding in its most basic form is the simple operation of identifying segments of meaning in your data and labelling them with a code, which can be defined as a word or short phrase that symbolically assigns a summative, salient, essence-capturing, and/or evocative attribute for a portion of language-based or visual data" (p. 3). Overall, the researcher employed the inductive coding approach which develops "codes from the data by using phrases or terms used by the participants themselves, rather than using the, often theoretical, vocabulary of the researcher" (Linneberg \& Korsgaard, 2019, p. 12). This ensured the researcher remained openminded as the analysis took place. 
For research questions one and three, the researcher combined three first-cycle coding techniques together to get an initial breakdown of the data: In Vivo, structural and values coding. These three techniques were based on Johnny Saldaña's 2015 publication The Coding Manual for Qualitative Researchers (2nd edition). According to Saldaña (2015), In Vivo coding, also known as literal or verbatim coding, "refers to a word or short phrase from the actual language found in the qualitative data record" (p. 91). This method is especially useful for interview transcripts. Namey et al. (2008) defines structural coding as "a question-based code that acts as a labeling and indexing device, allowing researchers to quickly access data likely to be relevant to a particular analysis from a larger data set" (Namey et al., 2008, as cited in Saldaña 2015, p. 84). Each research question utilized structural codes as noted in the following table:

\section{Table 7}

Structural Codes Used for Each Research Question

\begin{tabular}{|l|l|}
\hline \multicolumn{1}{|c|}{ Research Question } & \multicolumn{1}{c|}{ Structural Code(s) } \\
\hline $\begin{array}{l}\text { To what extent do teachers teach history through } \\
\text { historically marginalized perspectives, } \\
\text { specifically through Black voices and } \\
\text { perspectives? }\end{array}$ & $\begin{array}{l}\text { CONTRIBUTIONS, ETHNIC } \\
\text { ADDITIVE, TRANSFORMATIVE AND } \\
\text { SOCIAL JUSTICE }\end{array}$ \\
\hline $\begin{array}{l}\text { What challenges do teachers face in incorporating } \\
\text { Black voices and perspectives into their } \\
\text { curricula? }\end{array}$ & CHALLENGES TO INCORPORATION \\
\hline $\begin{array}{l}\text { What impact, if any, do multicultural teacher } \\
\text { resources have on an educator's restructuring or } \\
\text { reshaping of their own history curriculum? }\end{array}$ & RESOURCE IMPACT \\
\hline
\end{tabular}

Research question one's four codes came directly from Banks and McGree-Banks' 2016 multicultural education integration framework mentioned in the literature review.

Finally, Saldaña (2015) defines values coding as "the application of codes onto qualitative data that reflect a participant's values, attitudes, and beliefs, representing his or her 
perspectives or worldview" (p. 110). The researcher used value codes from the transcripts to analyze each of the three research questions. The combination of the three coding techniques gave the researcher a clear look into where each participant currently was in their integration of Black voices and perspectives within the curriculum. The researcher was then able to use value codes from the third interview to determine if participants' use of the New Visions resource would move them along that same integration framework. For research question two, values coding was also used to categorize the challenges of incorporating Black voices and perspectives into the curriculum. This was especially telling with participants' views on the various personal, student and administrative/community level challenges they faced when incorporating Black voices and perspectives into their curriculum.

Lastly, to understand those connections between the four participants, the researcher utilized a second-cycle coding technique known as the thematic analysis approach, or thematic coding. Braun and Clarke (2006) defined this method as identifying, analyzing, organizing, describing, and reporting themes found within a data set. King (2004) argued that thematic analysis is a useful method for examining the perspectives of different research participants, highlighting similarities and differences, and generating unanticipated insights and reporting themes found within a data set. The combination of these coding techniques provided clarity on topics, and allowed the researcher to find themes and connections between the participants.

The researcher presented the data from each of the four interviewees' interviews using Yin's (2016) model of interspersing quoted passages within selected paragraphs. The compiled data from interview one was used to assess where each educator currently was in Banks and McGee-Banks' (2016) content integration approaches detailed earlier in the study, thus answering research question 1. Compiled data from interview two was used to assess what 
pedagogical techniques were being used to teach Black history, thus answering research question 1a. Finally, the data from the third interview was used to assess possible growth, or shifts in their content integration based on the resources provided to them from New Visions for Public Schools (NY), thus answering research question 3. Data from all three interviews was used to answer research question 2, as each interview asked the interviewees to discuss challenges associated with incorporating Black voices and perspectives into their curricula.

\section{Assumptions and Limitations}

Because of the nature of the topic, participants may have self-censored their responses. The researcher was interested in making claims that the results from this study can generalize to the larger population. However, this study only examines four small, rural schools in the Midwest; therefore, the sample size is small when considering the amount of small school districts in the region. Due to the design of the study, the results are not generalizable.

\section{Ethical Considerations}

This study involved human participants. Thus, ethical considerations about informed consent and confidentiality of the subjects were vital. Prior to the study, the researcher took coursework in research methods and completed IRB training. The background of the study and all requirements for the study were explained to participants in a preliminary email. Their participation was voluntary. Names of teachers were not used, nor were they identified by their school. Research participants were not subjected to harm in any ways whatsoever, and full consent for recording was obtained from the participants prior to the study.

To conclude, this chapter explored the data collection methods and procedures of the study. Using techniques recommended by Saldaña (2015), Braun and Clarke (2006) and King 
(2004), the researcher developed codes to break down the qualitative data and find patterns among participants' experiences. The results of the analysis are found in the next chapter. 


\section{CHAPTER IV: RESULTS}

As all educators know, the experience of any two educators is not alike, yet oftentimes, shared themes across different experiences emerge. Through interviews, teachers' experiences, attitudes and perceptions of incorporating Black voices and perspectives into their history curricula were explored. This section presents the results of this research study and provides an analysis and discussion of those results. Each participant's teaching experience was detailed earlier in the paper.

\section{Banks and McGee-Banks' Levels of Integration}

As noticed from their current unit or thematic structures (found in tables 3-6), all four participants varied in their integration of Black voices and perspectives within their current curriculum. Each of four participants, no matter how many of their current units or themes already included Black voices and perspectives, stressed that further inclusion is a work in progress, and indicated the current political climate is compelling enough to get them reflecting on their curricula.

\section{Contributions approach}

The contributions approach is a baseline for every teacher looking to start their multicultural integration. This approach emphasizes ethnic "heroes and holidays" and places them throughout a curriculum without restructuring its foundation. Two teachers fall under this approach: Teacher $\mathrm{H}$ and Teacher A.

Teacher $\mathrm{H}$ described his use of the contributions approach through a technique he termed "dedicated days":

When we do dedicated days to look at the role of Black people and Black voices in American history, I try to make sure that we include some sort of writing so that they can 
actually engage with that voice and see like this is what was actually being said and not just have it be this abstract summary of this person and what they did. Um and really just like trying to incorporate primary sources that way, where it's like here's their actual voice.

These "dedicated days" are purposefully carved out within a unit, and are typically grouped together. For example, in his Gilded Age and Progressive unit, Teacher $\mathrm{H}$ set aside a three-day mini unit on marginalized voices of the time, including women, Blacks, and immigrants. After this mini unit was completed, Teacher H pivoted back to the so-called "mainstream" curriculum and those voices tended to be stuck in place. Teacher $\mathrm{H}$ stressed that in the early units, specifically American Revolution, Nation Building and the Age of Jackson, "I'm gonna be honest, like I don't do a great job, like it's definitely an area that I need to improve." Teacher H went on to explain that even though his American Revolution unit does include Black voices and perspectives, it only includes "the generic route" of Crispus Attucks and his death in the Boston Massacre. He further clarified the typical structure of his early units, saying:

It's mostly like we follow the pattern of here's the president, the major decisions they made and what would you do? And then the big theme for that one is grading in comparison. So, like, for Washington, Adams, Jefferson and Madison, I'm like here are all the major issues that they had, here's how they handled it. Grade them and then their big test (assessment) for that one is they have to rank the presidents and provide justification based off how they think they handled it. The closest we get is when we're talking about Washington and Jefferson in particular, inevitably, one of the discussions we have is, well, they were slave owners. So how does this, or does it affect them? But 
again, that's not really Black voices, that's more just exposing slavery in the United States.

When discussing that unit structure, Teacher H stated "it's just one of those things where it's never been super easy to fit into my current structure." The use of "dedicated days" forced Teacher $\mathrm{H}$ to dedicate time to the marginalized voices of history. Regardless of unit, each time Black voices and perspectives were incorporated, Teacher $\mathrm{H}$ referred to these dedicated days as a “Marginalized People's Day.” Teacher H further explained that in order to ensure any marginalized voice is taught, "dedicated days," are carved out within the unit for 1-3 days depending on the topic. An example of this comes below:

The way I do it for World War One is I again have a collection of primary sources so that when I do a collection of primary sources it has some letters and some personal experiences but then also a summary and we actually do that as a jigsaw over a couple days where it is just marginalized voices. So I have like Latin Americans, Black, Native American, women, Irish, like all of them get their own section and then we jigsaw out to where chunks of the class are responsible for each of those. And that's just kind of like our marginalized people's day.

Teacher A's use of the contributions approach proved similar, and he feared "isolating" the marginalized voices in his curriculum planning. Teacher A hoped to avoid this isolation, yet failed to do so saying:

What I'm weary of is making it into just like, these are people who have been abused in history, you know. I try and incorporate that bit of agency into it so that they are more so seeing it...It's hard to take time aside to go from that perspective and I guess where I've kind of run into roadblocks before is making sure that I want to do it right, you know, 
because I don't want it to just be like you know, like I said, oh, we're gonna talk about a, you know, really quick time where some people in the past have been abused and they were completely powerless and all right, move on, you know? I don't want it to just be a checkbox, which it can be and I'm sure it's been like that for me in the past.

Both Teachers $\mathrm{H}$ and A seemed to follow this structure in their integration: teach the mainstream content, and then sparingly include the marginalized voices of the time, and then pivot right back to the mainstream content. Those voices tended to get lost, and failed to form a complete story of the era being taught.

Teacher A was the only participant who specifically taught Advanced Placement US History; therefore, Teacher A noted feeling "blocked in," by the strict demands of the daunting AP curriculum pacing guide. Discussing this pressure, Teacher A responded:

I mean, because part of the issue is, like I said, I'm stuck to that kind of timeline. I've got an exam - I think the date is like May 4th or something - and I have to get through a certain amount of curriculum by that time and like Reconstruction, for example, is something that we're just talking about pretty much what I said I didn't want to do, which is like these are the you know, basically, the white approaches to Reconstruction, and this is how the southern Democrats wanted Reconstruction. This is how the Radical Republicans wanted reconstruction. And it's like, well, I really would have loved to take some time aside, to see, like, what is happening within these former slave communities. When discussing the structure of the AP units, Teacher A affirmed that content tends to focus on the "top level of society," and that even in a unit like Reconstruction, White perspectives are emphasized over Black perspectives. According to College Board's AP Course Framework for US History (2020), the learning objective for Topic 5.10, Reconstruction, states the following: 
"Explain the effects of government policy during Reconstruction on society from 1865 to 1877 " (p. 127). Broad in its scope, this objective clearly allows for the exploration sought by Teacher A above. Furthermore, one of Topic 5.10's "Historical Developments" specifically references "the rights of African Americans, women and other minorities" (p. 127).

Teachers $\mathrm{H}$ and A clearly fall into the Contributions approach as identified by Banks and McGee-Banks. By emphasizing "dedicated days" or "Marginalized People's Days," and relying on a strict, prescribed timeline, respectively, Teachers $\mathrm{H}$ and A's current integration approaches emphasize basic level integration, and fail to challenge the mainstream curriculum. The reliance on the inclusion of only the heroes of Black history such as Booker T. Washington, W.E.B. DuBois and Frederick Douglass clarified a "heroes and holidays" contributions approach. Teacher A also revealed the textbook titled The American Pageant, written by David Kennedy, Lizaveth Cohen and Thomas Bailey, is used, although sparingly, for the class. CBS News Investigative journalists Jericka Duncan, Shannon Luibrand and Christopher Zawistowski (2020) have heavily criticized this text for its depiction of African slaves as "immigrants," yet the text is currently on the College Board's list of textbooks that "meet the curricular requirements of AP U.S History" (para. 7). On page 85 of the thirteenth edition (2006), a map titled "Immigrant Groups in 1775," includes the following: English, Dutch, French, Germans, Swiss, Scots, Irish and African slaves. Furthermore, on page 84, the authors refer to slaves as "forced immigrants." When asked about this text specifically, Teacher A said "it will set aside a page where it'll be like Black voices on that page, and I think it does make a conscious effort to incorporate it." Both teacher $\mathrm{H}$ and A's reliance on using "time" as a crutch to hinder the incorporation of Black voices and perspectives further clarified a "heroes and holidays" contributions approach. 


\section{Ethnic additive approach}

The ethnic additive approach is a bridge to the transformative approach. This approach involves putting ethnic content into the curriculum without restructuring it. Referencing the current climate in this country, Teacher M said of her integration:

Um...my answer I guess has changed a lot since May of [2020] (referring to the murder of George Floyd). I have worked a lot on that. This past year, just trying to educate myself more and reading a ton more. So yeah, I can never say that my knowledge is adequate enough. I guess there's always so much more to learn. But over this past year I have made a concerted effort to learn more in recognizing the deficits of my own education. In terms of the different eras of history, what that meant for black Americans. So, yeah, so that just requires a lot of personal reflection.

Teacher M further compared her own education experience in learning US History to her current approach in developing her own curriculum. Teacher M stressed that it does take a "concerted effort" more than once to incorporate not just Black voices and perspectives, but marginalized voices overall:

As I'm sure you know, it does take a concerted effort especially if we are comparing that to when we were in school. You know, like I think that the approach to history has changed quite a bit to say, like we should be looking at multiple perspectives. So what that means for me is kind of going back on the assumptions that I've had for my own history education and trying to build on that with outside resources and with that, having the benefit of, you know, being a history major in college, knowing the importance of primary sources and where to find them. So, that's kind of my approach to incorporating marginalized voices is to show my students those primary sources that, you know, there 
were other people and other voices living in this time, not just the main ones we know about and that those hold equal weight in the context of that era.

In most of her units, Teacher $\mathrm{M}$ utilized primary sources to tell the story of the Black experience; however, most of those primary sources emphasized only the voices of well-known figures of Black history, something Teacher $\mathrm{M}$ was working on at the time to improve. Teacher M stressed that the available textbook, McDougal Littell's The Americans from 2009, is not used in her class, or involved in the planning of her class. When discussing the text, teacher M responded by saying "I think just from what I've looked through there, you know how textbooks will have that little like rectangle to the side? That's all it is." Teacher M further clarified that the text drastically oversimplified the experience of Americans of color, noting the text tends to treat their experience as "this is a person of color and this is their experience and this is one little blurb in the whole chapter."

Teacher M clearly fell into the Ethnic Additive approach. Her shared artifact emphasized two heroes of Black history (DuBois and Washington), and by incorporating Black voices and perspectives into most of her units, Teacher M's current integration approach emphasizes abovebasic level integration, yet still fails to transform the mainstream curriculum as mentioned by Banks and McGee-Banks (2016). However, Teacher M seemed to be on the path towards the Transformative Approach, and at the time of interviewing, was actively in the process of adjusting and enriching the curriculum to include more marginalized voices throughout each unit. Where teachers $\mathrm{H}$ and $\mathrm{A}$ lacked inclusivity in their curriculum pacing, Teacher $\mathrm{M}$ stressed the importance of incorporating more than just "heroes and holidays," creating a fully inclusive look at the "full American experience" saying "I don't want especially, like my students and 
where I teach to just start thinking, oh okay this is the you know marginalized voice part of the unit. My goal is to write this as a full American history experience."

\section{Transformative approach}

Teacher E was the most experienced teacher of all the participants, and the impact of having her mother as a teacher clearly had a profound impact on curriculum development. When asked to describe the incorporation of Black voices and perspectives throughout the curriculum, Teacher E responded:

This needs to be an ongoing thing...So I don't think it's okay to say 'okay now in this month we're gonna do this.' There's a lot of different ways that I bring different voices in...I also saw my parents as I was growing up, you know, speak out on Civil Rights issues with teaching us about Martin Luther King and things like that when we were younger.

Similar to Teacher M and the impact George Floyd's murder had on her curriculum adaption, Teacher E's curricular decisions are shaped by the events she grew up with, as well as the environment in which she was raised.

Early in the interview, Teacher E mentioned Howard Zinn as one of the historians she relied on as a foundational piece for the planning of her curriculum. Zinn himself is a controversial historian, and his landmark text A People's History of the United States, was used by Teacher E. Zinn has been described as a historian for the "left," according to the conservative learning Wall Street Journal. Teacher E said of her use of Zinn in the curriculum:

I do (use Zinn). Well, in fact, that was probably the first thing that really helped me to see some of the ways that I could teach the various voices and just as a little idea, that is the people's history (referring to A People's History of the United States). That's a huge 
foundation for my class. I start out with that at the very beginning of the year...I get pushback on Zinn. I get pushback from them (students) and they look him up and they say, 'oh he's an anarchist, oh, he's a socialist, So we shouldn't be teaching him.' Zinn's approach to history emphasizes the stories not typically told or even included in a mainstream curriculum. Using Zinn as a foundational text in itself challenges the very idea of a typical history curriculum. Teacher E does not just use Zinn; she supplements her curriculum with various historians including Carl Becker, Eric Foner and James Loewen. Loewen's works explicitly challenge mainstream history curriculums, with his most notable work, Lies My Teacher Told Me, being the end product of two years of studying high school textbooks at the Smithsonian finding bland optimism, blind nationalism, and plain misinformation (Huckleberry \& Berrey, 2021).

In terms of structuring the curriculum, Teacher $\mathrm{M}$ noted it is "people dominant...because it's the easiest way to get the kids to kind of know about different people and to understand what they experienced." Although the curriculum is people dominant, E avoids only including heroes and holidays, and layers the experience of the well-known heroes with the experiences of everyday Black Americans of the time, including the perspectives of Black shopkeepers, homeowners, and school teachers. Teacher M directly mentioned the 1619 Project podcast as an example of a "beautiful way of layering the story," expressing that's the goal in telling an absorbing, inclusive story. The 1619 Project, founded by Nikole Hannah-Jones, is a product of The New York Times Magazine and "aims to reframe the country's history by placing the consequences of slavery and the contributions of Black Americans at the very center of the United States' national narrative" (Hannah-Jones, 2019). Its highly polarized reception now includes state legislatures who have banned the project from being taught in public schools. 
Teacher E consistently expressed frustration when discussing the incorporation of Black voices and perspectives throughout her curriculum, saying "I think most of my students would tell you that that's all I teach," signaling the pushback she faced.

Teacher E clearly fell into the Transformative approach. By incorporating and emphasizing Black voices and perspectives in every unit, Teacher E's current integration approach emphasizes deep level integration, and challenges the mainstream curriculum as mentioned by Banks and McGee-Banks (2016). Teacher E seemed to want to do even more in her integration, potentially moving into the Social Justice approach, but seemed exhausted by continuous pushback from both students and the community, as will be described more fully in the Challenges section, describing it as "death by 1,000 papercuts." Teacher E modifies her curriculum each year to better realize the full American Experience and to live up to her course's title.

\section{Pedagogical Strategies Used in Incorporation}

The incorporation of Black voices and perspectives not only includes content decisions, but pedagogical decisions as well. Each of the four participants overwhelmingly aligned with current "best practices," including using primary sources and inquiry-based methods of study. The following table details the shared artifacts from each of the four participants. A discussion of the similarities and differences in pedagogical choices follows as shown in Table 8.

\section{Table 8}

Summary of Submitted Artifacts

\begin{tabular}{|c|c|c|c|}
\hline Teacher & Unit/Theme & Historical Topic & Pedagogical Style(s) \\
\hline $\mathrm{H}$ & $20 \mathrm{~s} \& 30 \mathrm{~s}$ & Harlem Renaissance & $\begin{array}{c}\text { Primary source-based } \\
\text { question/answer \& discussion }\end{array}$ \\
\hline
\end{tabular}




\begin{tabular}{|c|c|c|c|}
\hline A & $\begin{array}{c}\text { Imperialism \& } \\
\text { Progressive }\end{array}$ & $\begin{array}{c}\text { DuBois' \& Washington's } \\
\text { Views on Racial Equality }\end{array}$ & $\begin{array}{c}\text { Primary/secondary source-based } \\
\text { WebQuest \& discussion }\end{array}$ \\
\hline M & $\begin{array}{c}\text { Industry \& } \\
\text { Progress }\end{array}$ & $\begin{array}{c}\text { DuBois' \& Washington's } \\
\text { Views on Racial Equality }\end{array}$ & $\begin{array}{c}\text { Primary/secondary source-based } \\
\text { question/answer \& discussion }\end{array}$ \\
\hline E & Age of Diffusion & $\begin{array}{c}\text { Reconstruction } \rightarrow \text { Civil } \\
\text { Rights }\end{array}$ & $\begin{array}{c}\text { Primary source-based } \\
\text { question/answer \& discussion }\end{array}$ \\
\hline
\end{tabular}

Based on Table 8, each participant relies on the same general pedagogy when incorporating Black voices and perspectives: primary source-based analysis paired with some form of class discussion. Each shared artifact generally follows the same structure shown in Table 9 below:

\section{Table 9}

\section{Pedagogical Lesson Preferences When Incorporating Black Voices and Perspectives}

I. Context: short reading(s) or video(s) providing historical context or connections.

1. Comprehension questions may or may not accompany the reading or video.

II. Action: Students analyze various types of primary sources using historical thinking skills.

1. documents, photos, art \& poems were the most common types of sources used.

2. Structured questions varied by participant - most used some sort of "tool" to guide students in their interpretation of the source. Ex: Library of Congress

3. Teacher E stressed that this type of lesson is completed well after "historical thinking skills" are taught earlier in the semester.

III. Follow Up: Discussion follows student analysis of the sources.

1. Typically start with small groups and transition to the whole class.

2. Teacher $\mathrm{H}$ was the only participant to specifically reference the Socratic Seminar as a preferred method.

When incorporating Black voices and perspectives into the curriculum, Teacher $\mathrm{H}$ preferred "trying to incorporate primary sources, that way, we're like here's their actual voice...I think that they do a good job of telling about history, but, like, in trying to give voice to a group, usually, I look towards art and/or letters." Teacher A had a similar response, saying "the main 
way I'm gonna do that is through various documents...but like not focusing on necessarily what has been said about those groups but like what is their own discussion?" Teacher M also emphasized a reliance on primary sources, but stressed filling the "gaps" of what is left behind when stereotypical Black history is taught. Stereotypical, to Teacher M, is similar to Banks and McGee-Banks’ Heroes and Holidays approach. Teacher M highlighted:

Not just telling kind of the typical narrative of what Black history has looked like in this country. I think there's a lot of gaps there so that has been my you know, I guess, core aim this year is to actually incorporate that each and every unit and not just to say 'slavery, Civil War, Civil Rights.' There's so much in between that and so, it does truly start with this.

Lastly, Teacher E experimented with the incorporation of different media into the curriculum, especially as they related to Black voices and perspectives. Teacher E specifically referenced podcasts, folk music and films. Teacher E uses The New York Times Magazine's 1619 Project, which was received with some pushback (to be discussed later), and mentioned folk music's Kate Campbell and the Hollywood film Glory. Teacher E tends to blend primary sources together with role plays, too, saying "I think the role play is really important too, because it forces them to contextualize...I mean, people keep telling me how we have to teach empathy and I've always taught empathy...so the role play is really important because it makes them 'step in those shoes."' This specific role play described by Teacher E was based on a lesson plan found within the Zinn Education Project's website, and focused on Redlining's impact on Black Americans. According to the Zinn Education Project description, this "mixer" activity has students "meet people who fought bravely against this dizzying array of racist policies." The 
lesson plan was adapted by teacher E to connect back to topics like the Civil War, Reconstruction and the KKK.

\section{Challenges Facing Participant Incorporation of Black Voices and Perspectives}

All four participants faced various challenges in their integration of Black voices and perspectives within their current curriculum. The researcher used three categories to provide clarity on the challenges facing the participants: student-level challenges, district-level challenges and community-level challenges.

\section{Student-level challenges}

Teacher $\mathrm{H}$ started each class that covered a topic relating to a marginalized group with a disclaimer of sorts, stating:

I think some of the reason we don't have pushback is because I've made it very clear that this is a thing that I think is very important and needs to be discussed whenever we talk about it because every time we have a lesson on marginalized voices, I always start the lesson by saying, like, 'hey this is a big deal... we're not gonna joke about this,' like this is a thing that is oftentimes neglected and we need to acknowledge because like it's not a great moment for the world or for our history, our own personal history. And so, I think I've built this culture of like whether you agree with it or not, like this is something that I (Teacher H) care about and if you don't treat it appropriately, I will get angry."

This type of "disclaimer" seemed to be a reoccurring requirement at the beginning of any lesson dealing with marginalized voices throughout US History. Teacher A expressed having similar conversations and experiences, instead noting student "weariness." Teacher A responded:

I do not. I would not say that I experienced pushback, but you can sometimes feel a little bit of, you know, weariness. So I try to do my best when we talk about, you know, 
sensitive topics in any of my classes. I come out and I'm like, listen, nobody is trying to offend anybody here. Nobody is trying to make fun of anybody, okay? Because sometimes I think there is a hesitancy to make certain comments because they're (students) afraid of how it would be perceived. So I have to, you know, I go out of my way to reinforce, like, I know you're not trying to say anything bad here.

Teacher A also prepared a "disclaimer" of sorts for his students, saying Oh, I do that in pretty much any of my classes. Whether we talk in Sociology, Civics, or AP US History, I feel like it's important because kids are worried, you know. They are aware of how things that they may say could be perceived by me especially or by, you know, their peers.

This fear of perception really stood out. The fear of being called "racist" by peers was a common incident mentioned by Teacher A. Both $\mathrm{H}$ and A seemed to expressed frustrations that their students felt these types of topics were forced on them, and this seemed to be the root of student pushback.

Unlike $\mathrm{H}$ and $\mathrm{A}$, Teacher $\mathrm{M}$ did not seem to experience the pushback or weariness as Teachers H and A did. Teacher M framed her US History class as one "American experience," inclusive of all people. Teacher M, a past graduate of the school and in her seven years as a an employee there, has worked to create an inclusive and empathetic learning environment in her classroom:

I never have. I don't know if that's just something they're (students) not gonna do outright, you know, who knows what their conversations are like, but again like that's where I really try to not like not draw attention to it, but not treat as something other, you know, but to say like this is an American experience and this is what matters. I think I 
had to, you know, make a certain effort to frame it like that for these students. So I have not felt any pushback in that regard especially in US history or anything.

Unlike the other participants, Teacher E experienced extreme amounts of pushback from students. Teacher E falls within the Transformative integration approach, and her curriculum caused tension amongst the student population, even earning a reputation amongst students as a "liberal indoctrinator." Teacher E shared numerous personal stories of student pushback and frustrations over the past years. In the excerpt below, she talks about physical damage caused by students:

It has been challenging even to just be that teacher that stands there and tells them things they don't want to hear. Um, it's been hard on me emotionally and psychologically...I've had Obama's eyes gouged out (referring to a lifesize cardboard cutout). I've had Obama's whole head gouged out on these things that I have on my wall. I keep them up because I want them to know that, you know, this is violent. A young lady that I had in my classes was Japanese-American. Her mother is of Japanese descent and her father was just a local person...She wrote two books of poetry, so I have her picture up on my wall. Her face is all scratched out. Obama's poster was stolen as well and so now I got a new poster saying 'this is the property of Unit School District ***' in red letters because it's stealing, you stole my poster and it wasn't mine, it was the schools. I bought it with school money. Um, so yeah, so there's those kinds of things that happen. Subtly. Not so subtly.

When interviewing, Teacher E's emotions were clearly on display, as well as the frustrations surrounding years of student pushback. At times, she would even pause to collect her thoughts. Clearly, twenty-plus years of pushback has taken a toll. Teacher E feels as if the demeaning label 
of "liberal indoctrinator" is now a well-known reputation, and one that affects her mental wellbeing as a member of the community.

\section{District-level challenges}

Concerning district-level challenges, Teacher $\mathrm{H}$ expressed frustration with lacking a "well established curriculum," saying

So, I've never really had a good idea for what one (curriculum) looks like. Once I was out of college, my support for good resources kind of dropped away. So, I imagine they (district administration) would be willing to get new materials if I wanted them, but honestly, I just don't even know where to look half the time.

Teacher $\mathrm{H}$ reaffirmed that the administration would be willing to supply new materials to help incorporate Black voices and perspectives as long as he "clearly justifies it." Teacher H's school did not have any curriculum coach or director at the time of interviewing. In small schools like H's, this position is often absorbed by other positions and encompasses many duties including Response To Intervention (RTI) and state-mandated testing support.

Of the four participants, Teacher A did feel most supported by administrators, and felt as if they were willing to provide financial resources if requested, saying

I think that is something that they're (administration) making a conscious effort toward with all and I know we're focusing on Black voices, but, you know, LGBTQ voices are encouraged and immigrant voices. I've been encouraged to incorporate those things. So I think there is that support for sure."

Although Teacher A has never requested financial support for curricular resources, A noted that "I feel like I would have a good chance of success." 
Similarly, Teacher M felt supported by administrators, but stressed that funds are tight right now. Teacher $\mathrm{M}$ said, of administration purchasing new materials:

Um, twofold. They absolutely would support any curriculum suggestion I make. I feel very supported where I'm at. I think it helps that my current superintendent was a former social studies teacher. The current principal is a former English teacher, and I think they 'get it' in terms of wanting to incorporate different perspectives. Financially, we just don't have money. So actually, this summer, I bought a class set of novels for my Sociology class (using her own money).

This is not a new problem for teachers, especially those in small schools who rely on typically older textbooks and curricular resources. According to a Department of Education survey from 2014-2015, 94\% of teachers spent their own money on their classroom without reimbursement from their districts.

Different from the first three participants, Teacher E feels somewhat supported by administrators. Unlike any other participant, Teacher E quickly responded that she has received prior pushback from administration concerning her curricular choices:

You know, this year, when we (admin and teachers) were talking about these ideas of, you know, how the kids treat us differently because they see us as liberal, he (superintendent) said 'if it is in your curriculum, I support you. If it's something that you've been doing, I support you. If you have questions then go ask the principal.' I've been doing this for so long, I'm not going to go ask him, but I did ask him about (teaching) Stonewall. He did not want me to do it. And so, I did not.

Teacher E also mentioned bringing up the idea of a staff book reading to happen over the Summer of 2020, right after the murder of George Floyd. Teacher E brought the idea of reading 
White Fragility by Robin DiAngelo up to their administrators and was immediately turned away.

\section{Community-level challenges}

Concerning community-level challenges, Teacher $\mathrm{H}$ did not express much issue here. However, the current events of 2020 did come into his classroom discussion of the Boston Massacre, and the discussion "carried over into some other classes where it continued and so the discussion that he (principal) had with me is that this needs to be kept in the history classroom." Teacher $\mathrm{H}$ clarified that a parent had called in to speak with the principal about the matter. Similarly, teachers A and M did not express much issue when specifically concerning Black voices and perspectives. However, teacher A did express concern surrounding community pushback towards the upcoming teaching of LGBTQ+ history in Illinois:

I would say, not as much for Black voices. The one that I think is more of a touchy subject would be the 'LGBTQ things.' That one I think is more of you can sense the weariness and you can see conflict. Not like outright conflict, but, you know, tension, I guess between students over that one, and obviously, that's gonna bleed its way up into their guardians. I would say that's more of the sensitive topic partially just because the percentage of Black students in the school is so low. You know, you may have multiple students who would identify as being a part of the LGBTQ community in your class and you might have zero Black students in any of your classes. So it does, I think, kind of like set up the conflict there, a little bit more.

Again, the State of Illinois, as of July 2020, now mandates that public schools incorporate LGTBQ+ history into their curriculum. 
Teacher $\mathrm{M}$ has never personally felt direct community pushback, but did notice a recent trend since the Trump presidency:

I think the greater fear is just when this becomes politicized, like, that's the fear in this community. And so, we're actively working as a staff. There are a few of us, some administrators, in terms of what it means to, I guess care for our students that are, you know, diverse in some way. In terms of socioeconomic status, background, whatever. And so, it was a small community group that kind of approached the school and said, hey, we think there can be room for improvement, district-wide, and so we're actually working with them. I guess you can almost call it a 'Diversity Council' of sorts. So that's the ultimate goal. We're still in the early stages of it, but that was kind of approached to us from some community members.

Although Teacher M praised this newfound "Diversity Council," M expressed potential fear of community perception, saying "We also don't want our efforts to be perceived by the community as being reactionary to the climate of the era, you know what I mean? Because that is so easy for them to latch on and then just call that, you know, some kind of agenda." Clearly, the highly divisive political climate in this country lingers over schools heavily in decision making.

Unlike the first three participants, Teacher E did feel community pushback from the community in which she lives, and even grew up in, focusing on the "false perception" of her teaching reputation in the community, sharing this personal story:

I'm more fearful of the pushback commentary from the community. I have had a number of people who have come to my classroom or have had their children in my classroom tell me, oh, we heard something out there and you're not like that at all. You're very fair, you're very balanced. My teaching assistant (TA) right now, when she was at the middle 
school, heard all kinds of stuff about me. I grew up with her. She was a junior when I was a freshman. She's in my classroom now. I was really nervous to have her. I didn't know that anybody was saying anything about me at the middle school. The teachers and the parents were talking about that I was just so radical and that she's (TA) really conservative. She's a Trump supporter. Um, she didn't like him as a person, but she likes his policy, so we've had that discussion. But anyway, I've had her in my class for probably five years and she's willing to go to bat for me. She will stand up for me. She's not afraid to talk truth-to-power. So I know that I'm doing a good job, it's just sometimes, as a friend of mine said, it's death by 1,000 paper cuts.

Although Teacher E struggles with student pushback on what seemed to be a daily occurrence, E confirmed that "by the time students are seniors and they're done with my class, they have a good understanding that I'm not here to indoctrinate them."

\section{Impact of Introducing New Visions for Public Schools}

After completing the first two interviews, all four participants were introduced to a curricular resource unfamiliar to them called New Visions for Public Schools (NY) Social Studies Curriculum. This resource was described earlier in the paper. Each participant was given two weeks to look at and analyze the resources provided. Each participant's own experience with the resource was discussed to understand what impact, if any, the resource could have on their curricular decision-making moving forward.

\section{First Impressions}

Each participant was asked to explain their first impressions of this new resource. Their impressions are summarized in Table 10. Overall, each of the four participants felt that New Visions brought something new or positive to their curriculum planning. The first impressions by 
each candidate reveal a common theme: teachers are actively engaged in assessing their curriculum, and whether or not it meets a level of acceptability as determined by their own values.

\section{Table 10}

First Impressions of the New Visions Resource

\begin{tabular}{|c|l|}
\hline Teacher & \multicolumn{1}{c|}{ First Impressions } \\
\hline $\mathrm{H}$ & $\begin{array}{l}\text { Layout of the website is easy to navigate; units are nicely categorized with topics; } \\
\text { very well organized and clear }\end{array}$ \\
\hline $\mathrm{A}$ & $\begin{array}{l}\text { Simplistic layout and impressed by curricular choices (content); explicitly } \\
\text { stresses the importance of multicultural topics throughout units; assessments are } \\
\text { similar to AP style assessments }\end{array}$ \\
\hline $\mathrm{M}$ & $\begin{array}{l}\text { Appreciated emphasis on primary source pedagogy and emphasis on historical } \\
\text { literacy; lacked depth with multicultural topics available }\end{array}$ \\
\hline $\mathrm{E}$ & $\begin{array}{l}\text { Impressed by the sheer amount of primary source documents available; teaching } \\
\text { timeline is provided as a guide for teachers; Google Suite-ready; partnership with } \\
\text { Facing History and Ourselves is excellent }\end{array}$ \\
\hline
\end{tabular}

\section{Planned Teacher Use of New Visions}

Teacher H, during the two-week exploration period, incorporated two different lesson ideas from New Visions into the curriculum. Teacher H noted "I do want to say right off the bat that I really appreciate the major events in African American history timelines that both of these have so we can put things into context - I think that's excellent.” New Visions provides assessments for each unit as part of their curriculum. Teacher H noted that their (New Visions) assessments were "opinion-based," and emphasized the incorporation of historical evidence to substantiate claims. New Visions follows that same "historical thinking" method and this closely aligned with Teacher H's assessment style. 
Although Teacher $\mathrm{H}$ did plan to incorporate resources from New Visions, he stressed that it would probably not encourage him to restructure his Contributions approach curriculum: I don't think I'll be restructuring units, but I will be slotting these (sources) in more. But I think, like we've kind of talked about, I think the way I've structured my stuff thus far makes it pretty easy to slot them (Black voices and perspectives) in with just about every major event. I usually try and have a chunk of, like, this is how it affected normal people, and when I have had those minority voices, they get a day to themselves. Oh, in that, like, if it's a three-day sequence of, like, here's how it affected normal people, we just do like everybody and then like minority voices, be it like women, African Americans or Native Americans. So, it'll be really easy to just kind of slot them in and say, okay, I just add a day or two here.

The continued use of Teacher H's “dedicated days" did not seem to be challenged by New Visions. This rigid structuring of "dedicated days" reveals little flexibility in the incorporation of Black voices and perspectives. The idea of labeling curriculum as "normal people" and "minority voices" shows little to no flexibility in how Teacher H approaches the incorporation of Black voices and perspectives.

Teacher A was especially impressed by New Visions as a "database” of sorts. Teacher A said "I think in general, it's really helpful as like almost as like a little bit of a database for documents, you know, just finding that was one thing that I was just like, wow, I 100\% will be coming back here for documents because it has a lot of great ones and they're from good perspectives." In interview one, Teacher A voiced that finding challenging, yet engaging sources for his AP students was a challenge. New Visions provides sources that are "chunked" for students. 
In terms of assessment, Teacher A found New Visions aligned closely to the skills currently being taught in the AP curriculum, saying:

It is very similar in a lot of respects to the AP curriculum and the AP materials with different question types and the skills. I think one thing I said is it uses a lot of the same skills with different terminology. It's you know, the same thing, but different kind of wordage they're using. So very, very similar in terms of document-based questions and inquiry-based things.

Though Teacher A did plan to use New Visions as a mini-database for documents, Teacher A did mention that New Visions would prompt him to restructure his current Contributions approach curriculum:

Yeah, I think definitely, um, because you know I'll stick on that Reconstruction document-based question. I can come up with the practice questions and our practice questions don't have to be the same thing that's going to be on the exam as long as they're doing the same thing. You know, as long as they're still using the documents in the way that the AP rubric says, you know, I can still shift my focus a little bit and I think that's what I'm taking away from a large part is like...where you can shift your emphasis and how you can shift your focus because even if they don't get that same document-based question on the exam, there's still using it as practice.

A reliance on the scripted, time-strict AP curriculum will continue to hinder Teacher A, but New Visions did impact how Teacher A viewed his previous teaching perspectives that focused on the upper levels of society. Teacher A's stresses were rooted in the fear of his students underperforming on the AP test that occurs each year in May. As a young teacher, he felt he needed his students to perform at a high level in order to better solidify his status as a teacher in 
the district. To him, low student scores could ultimately impact a potential hiring decision. Teacher A realized during interviews that his lack of incorporation and fear of students underperforming on that test did in fact correlate, and he showed flexibility in his desire to incorporate more Black voices and perspectives into his curriculum.

Of the four participants, Teacher $\mathrm{M}$ was the only one engaged in active curriculum revamping and did not feel that New Visions would help her with that process:

Um, I don't know if I would say that this source is gonna cause me to modify my curriculum. But again, using it as supplemental materials. I think this is also an interesting consideration for (school name) specifically, because next year, my junior US History will be standards-based grading which changes some of the assessment styles that I'm looking for. So that's why I wouldn't say it's gonna overhaul my curriculum, but I think it'll provide good resources for classes.

Teacher E was the most critical of the group, and felt that the content choices (specifically relating to Black history) made by New Visions were "on par with what I've seen elsewhere." Viewing New Visions from a critical lens reveals M's great flexibility in the incorporation of Black voices and perspectives.

Of each participant, Teacher E was furthest along the integration scale proposed by Banks and McGee-Banks (2016), but still felt that New Visions would help restructure or modify her current curriculum:

Yeah, I think because there's always new information that becomes available as we know more things, historically...That's what's cool about history is, it's not that we're changing, the narrative, it's that we can add things to the narrative. So yeah, I would say yes. 
In terms of assessment, Teacher E felt New Visions solidified the teaching of historical skills throughout each resource, and would be especially useful in introducing these skills to students early in the year as well. Teacher E mentioned using this resource in conjunction with "the Stanford University stuff." Teacher E was referring to the Stanford History Education Group, or SHEG, whose goal is to act as an "incubator for new ideas about teaching students how to read historical texts and think about them in creative ways" (Stanford History Education Group, 2021). Teacher E mentioned wanting to create a more efficient way of teaching "the idea of looking at sources, contextualization, corroboration and the use of evidence through crosscurricular cross subject areas and then within our own departments...so this might help our social studies department, anyway."

Teacher E viewed New Visions as a new voice in her curriculum, showing great flexibility in the incorporation of Black voices and perspectives. Her avoidance of the mainstream curriculum and one-sided narrative shows great flexibility and inclusivity. 


\section{CHAPTER V: CONCLUSION, DISCUSSION AND RECOMMENDATIONS}

This study was conducted to examine the extent to which four teachers incorporated Black voices and perspectives into their current curriculums and their attitudes toward modifying the curriculum to make it more inclusive. Each of the four participants faced challenges when planning to incorporate Black voices and perspectives. They stemmed from a being unaware of already available resources and pushback from students or the community. Lastly, each of the participants recognized the need for resources such as New Visions for Public Schools to become widely known to social studies teachers. They also stressed a need for more time to dissect these resources. The research questions for this study are repeated below:

\section{Summary of Research Question Findings}

1) To what extent and how do teachers teach history through historically marginalized perspectives, specifically through Black voices and perspectives?

2) What challenges do teachers face in incorporating Black voices and perspectives into their curricula?

3) What impact, if any, do multicultural teacher resources have on an educator's restructuring or reshaping of their own history curriculum?

The conclusions of this study were:

1. The social studies teachers who participated in this study need access to good, substantive resources revolving around Black voices and perspectives. Preparing teachers to be multicultural educators goes hand-in-hand with this recommendation. Teachers need to be supported at the administrative level and challenged to modify and reform their curriculum to be more inclusive of all marginalized voices. 
2. Participants were not homogeneous in their content-based approaches to incorporation, but were in their skill-based approach.

These conclusions will be further described in the following sections.

\section{When and Where Do We Find Stuff?}

Throughout this process, recurring themes kept coming up when talking about modifying curriculum to make it more inclusive: using time as a crutch and locating worthwhile resources. Each of the four participants mentioned, in some form, the idea that "time" hindered them in some way. Whether that included the ability to get through content, being pulled in various directions by extracurricular duties or finding time to create or modify curriculum, each participant struggled with it. Each of the four participants were involved in some sort of extracurricular responsibility. For example, in interview two, Teacher A nearly had no voice from his extracurricular duties, and in interview one, Teacher E discussed the pushback received due to being the sponsor of a certain school club. All four participants felt crunched for time both in-and-out of the classroom in terms of planning curriculum. According to a 2012 study conducted by the National Council on Teacher Quality, most teachers have about 45 minutes of planning time per day within their contract hours. This can range from 12 to 80 minutes for elementary teachers and 30 to 96 minutes for secondary teachers, depending on school schedules. Outside of those typical 45 minutes, most of the remaining time is spent directly with students. These findings correlate with Washington and Humphries' work (2011) that shows the impact a lack of preparation can have on educators. When teachers are not adequately prepared, they tend to rely on "what they know" which generally leads to a "trial by fire" approach and shying away from tough topics. 
To complicate this even further, teachers spend little time collaborating with their colleagues. According to a Scholastic and Gates Foundation 2012 study, teachers are isolated from colleagues for much of the day, spending less than $5 \%$ of their work time collaborating with peers. In this study, which prioritized smaller schools in Illinois, the idea of a social studies department was almost nonexistent. Only Teacher E had multiple colleagues in the social studies department - Teachers H, A and M either taught all of the social studies offerings, or had only one other colleague. Less or no collaboration time leads to increasing time demands when creating or modifying curriculum.

One would think that in the age of the internet, finding engaging primary and secondary sources would be quite easy for the modern social studies teacher; however, each of the four participants mentioned, in some form, the idea that "school-ready" resources are hard to come by. The lack of time is often coupled with the difficulty of finding those "school-ready" resources. A "school-ready" resource is one that is immediately available and ready for students without needing excessive adaptation. For example, when looking at the comparisons between Malcolm X and Martin Luther King Jr., a prime source to study would be Malcolm X's 'Ballot or the Bullet" speech. This source is engaging, and provides a critical lens for students to make implicit modern connections to the Black Lives Matter movement. It also presents an opportunity for the class to engage in a social justice curriculum as mentioned by Banks and McGee-Banks (2016). Students can make public service announcements about the BLM movement and even debunk fears associated with the group. But on the other hand, this speech cannot simply be given to students to read without proper context or annotation. To fully realize this speech, the teacher would have to "chunk" it, provide vocabulary definitions, write scaffolding questions, and much more. Again, all of that involves time, which, as stated above, is clearly lacking. 
Resources such as New Visions provide these "school-ready" resources for teachers to use. However, these resources have to be discovered, and oftentimes, have to be paid for. Of course, numerous free resources are available for social studies teachers, but key components of forming curriculums such as graphic novels, texts, primary source sets, artifacts, etc. are not free and require substantial funding. According to a study conducted by Okongo et al. (2015), which was designed to assess the impact on which a lack of funding has on the development of an inclusive education, "78 percent of the respondents revealed that inadequate resources affected the implementation of inclusive education" (p. 132).

Lastly, preparing content teachers to be multicultural teachers is a critical pairing with providing resources. Of the four participants, each of them felt their own knowledge of Black history, or non-mainstream history, was still developing through their own learning outside of the classroom. In terms of pre-service teaching candidates, requiring more than minimal multicultural education classes would have a profound impact on multicultural competencies. In her Master's Thesis research, Olson (2003) found that after taking only one multicultural education class, students anticipated addressing multicultural issues in their classrooms more after completing the course than they did before completing the course. They also reported fewer personal attitudes that may prevent them from making use of multicultural approaches within their classrooms. Students also believed that they were better prepared by their courses to deal with multicultural issues in education after completing the course than they did the first day of the course.

\section{What They Taught Vs. How They Taught}

Prior to interviewing the participants, I expected that these four teachers, given they all teach in demographically similar, small, conservative towns within the same school conference, 
generally would fall into the same incorporation categories; however, that expectation was wrong. Although $\mathrm{A}$ and $\mathrm{H}$ both fell into the contributions approach, they were still vastly different in their incorporation of Black voices and perspectives from a content standpoint. They each decided to cover their own preferred topics when Black voices and perspectives were included; however, they each had similar pedagogical approaches. Each teacher taught different types of historical content, with each focusing on Black history's heroes at a minimum, but then veering off to include other topics such as redlining and life for Black veterans after coming back from war. Teachers $\mathrm{E}$ and $\mathrm{M}$, who fell into the transformative and ethnic additive approach, respectively, incorporated a more diverse array on Black history topics compared to participants A and $\mathrm{H}$, who specifically focused on the heroes of Black history only. This wide disparity in incorporation reinforces the suggestion that educators seem to view teaching about race as being forced and not within the normal pedagogy for the class (Chandler, 2009).

This range of content integration is also undoubtedly due to the lack of federal standards dictating what history curriculums should teach, along with the Illinois State Standards being exclusively skill-based and not restricted by content. This diversity of content is both positive and negative. It provides social studies teachers with an open net for curriculum and allows teachers to explore deeply certain topics; however, as the results show, this freedom can negatively impact a curriculum if only the heroes and holidays approach is followed. As Busey and Russell (2016) revealed, a low level of multicultural content in the curriculum only supports the development of white learners' identities. In these small schools, minority students are then left behind and neglected in their learning and interests. White students are thenleft with a distorted image of history and a skewed perspective about the current struggles for justice. 
Since the Illinois State Standards, Common Core and C3 Standards are all skill-based, each of the participants approached the content in the same way: via primary sources, discussion and critical thinking. This continuity in their pedagogy can also be due in part to the overabundance of teacher professional development over the past five years advocating inquirydriven history.

\section{Demographic Impacts}

The following unanticipated demographic impacts emerged from this study:

1) Female teachers exhibited more bravery in their incorporation of Black voices and perspectives.

2) Teachers with more experience were further in their incorporation of Black voices and perspectives into the curriculum.

3) Communities' political leanings do in fact have a significant impact on curricular choices made by teachers.

These unanticipated impacts will be further discussed in the following sections.

\section{Gender and Its Role on Curriculum}

After interviews were completed, it was found that the female participants (E and M, who were both more experienced as well) both incorporated Black voices and perspectives on a much deeper level compared to the male participants (A and H). Of the two female participants, Teacher E also experienced the most severe, even violent pushback from students as well, including defacing property within her own classroom and being labeled a "liberal indoctrinator." Neither male participant (A and H) experienced this severe pushback. This lacking respect for the authority of female teachers correlates with research from Tracy Darrin Wood (2012) who surveyed 215 elementary teachers about gender perceptions. Wood's survey 
data revealed multiple respondents reported that "men in their building garnered more respect because of their gender" (p. 330). Wood's research also revealed that male teachers tended be viewed as stricter and disciplinarian compared to their female counterparts. However, teacher M did not experience this type to severe pushback.

Both female participants incorporated Black voices and perspectives on a deeper level, and this deeper integration may correlate with the following:

1) For many years, women have been marginalized in both historical textbooks and curriculum. Therefore, both female participants may have felt some type of obligation to include all marginalized voices on a deeper level since they identify with those groups.

2) Women are more likely than men to identify as Democrats, or liberal. According to a 2009 Gallup poll, $41 \%$ of women in the nearly 150,000 surveyed identified as Democrats, compared to $32 \%$ of men surveyed. In general, the more liberal a teacher is, the more willing they may be in incorporating marginalized voices.

To be clear, these links between gender and curriculum are unproven, but patterns did emerge from the data to support further research concerning gender perceptions of teachers and the impact gender has on social studies curriculum development. It is also important to refer to Table 11, which reveals both female teachers were also tenured at their respective schools.

\section{Teacher Experience and Risk Taking}

Although each of the four participants approach the incorporation of Black voices and perspectives in similar fashion, the depth of which those voices are explored and incorporated into the curriculum varies distinctly. The main factor that seemed to differentiate participants seemed to be years of teaching experience. Table 11 summarizes each participant's tenure status and their multicultural integration level according to Banks and McGee-Banks (2016): 


\section{Table 11}

Teacher Experience Level Paired with Integration Level

\begin{tabular}{|c|c|c|}
\hline Teacher & Tenured? & Multicultural Integration Level \\
\hline H & No & Contributions \\
\hline A & No & Contributions \\
\hline M & Yes & Ethnic Additive \\
\hline E & Yes & Transformative \\
\hline
\end{tabular}

Although Teacher $\mathrm{H}$ had enough total teaching experience to earn tenure, $\mathrm{H}$ did not have enough at his current school. Only Teachers $\mathrm{M}$ and $\mathrm{E}$ had tenure at the time of interviewing, and both of these teachers were outside of the Contributions approach. Tenure can certainly provide some comfort to teachers wanting to push boundaries with their curriculum, and that seems to be the case with the participants in this study. This notion is consistent with research from Jones (2015) who used survey data from the Schools and Staffing Survey to find that tenure is effective in reducing concerns about job security.

The participants differed most in the pushback they received from students, administration and the community. The more experienced teachers (Teachers $\mathrm{M}$ and $\mathrm{E}$ ) clearly felt more comfortable taking risks opposed to the less experienced (Teachers $\mathrm{H}$ and $\mathrm{A}$ ). Ronald Beghetto, professor of educational psychology and director of the Innovation House at the University of Connecticut, discussed what he calls "beautiful risks." According to Beghetto, "a beautiful risk involves taking actions that have the potential to make a positive and lasting contribution to the learning and lives of others" (p. 19). In order for these "beautiful risks" to occur, educators must create opportunities in the curriculum for them, which inherently involves taking risks. Beghetto continues saying "although doing so requires us to let go of some of the 
certainty of more defined and structured approaches, the potential benefits to our students include deepening their engagement, developing their creative confidence, and providing them with opportunities to contribute to their own and others' learning" (p. 19). Those so-called defined and structured approaches can be the mainstream-centric curricula for social studies teachers. This type of curriculum is typically pre-created and requires less additional outside learning and work for the educator to prepare and present to students. However, this reliance on the mainstream curricula eliminates Beghetto’s “beautiful risks.” It also contradicts the changing ideas of what a $21^{\text {st }}$ century educator is in the classroom. Fullan and Langworthy (2013) note that teaching is "increasingly seen as an equal two-way partnership between and among students and teachers" (p. 851). Howard et al. (2018) define $21^{\text {st }}$ century educators as social innovators who develop creative pedagogies. A mainstream centric curriculum does not require creative pedagogies.

\section{Political Climate's Impact on Curricular Decisions}

Each of the participants were selected in part based on their town's political leanings. Of the thirteen towns available, all of them are heavily conservative. The researcher was interested in seeing the impact this had on curricular choices. Expectedly, the town's political leanings did have a significant impact on participants' curricular choices. This correlates closely with the work done by UCLA's Teaching and Learning in the Age of Trump team in both their 2018 and 2020 studies mentioned earlier in the paper.

This impact dictates the amount of outside pressure on teachers to stay within acceptable boundaries (as determined by town norms). The boundaries were typically set by parents and their disdain for certain topics or discussions that took place in the classroom. For example, Teacher M, who teaches in one of the most conservative towns chose to cover multicultural 
topics and was actively involved in revamping her curriculum to include even more on a deeper level. She never received direct pushback, but was always aware of being labeled a potential "agenda setter." She was fearful of actions being politicized within the community. As mentioned earlier in the paper, Teacher $\mathrm{H}$ was directly confronted by administration for a Black Lives Matter discussion, and he tended to shy away from that for the rest of the units moving forward. Every participant expressed some sort of community pushback, whether it involved fear of incorporating LGBTQ+ history, setting "agendas," parents calling in to the principal or being unfairly labeled. All of these must constantly weigh on teachers when planning their units or themes.

Other research by Bar-Tal and Harel (2002) supports the idea that teachers are constantly maneuvering between being a political influence on students or simply being neutral on controversial, difficult topics like race. Bar-Tal and Harel interviewed over 800 Israeli high school students and their data showed that sixty-eight percent of students reported at least one teacher had influence on their political attitudes, while thirty-two percent did not think that any teacher had such influence on them. It was found that those teachers who were labeled as influences typically taught social sciences and the humanities. They were also found to be more progressive, democratic, and dovish in their political beliefs. In states like Illinois, in which standards are not explicitly tied to content, this political identity can ultimately impact curricular decision making. Teachers' decisions concerning curriculum resources and content are inherently political and tied to political identity. 


\section{Implications}

\section{Practical Implications}

The current study offers practical implications for both educators and administrators. In this study, the findings demonstrate that educators do in fact struggle in their incorporation of Black voices and perspectives into the US History curriculum.

For administrators, the results of the research questions reveal educators need support from administration in taking risks, seeking out and purchasing rigorous, inclusive resources and feeling safe and confident in their position. Open lines of communication are needed to accomplish this, and the age-old teacher evaluation system that encourages random, spurious classroom visits simply will not work. Administrators must ensure adequate teacher prep time is built into the school day and allow teachers to work collaboratively with others. This may also include creating partnerships with outside school districts for educators to discuss curricula sideby-side. Utilize curriculum or instructional coaches to foster collaborative relationships in developing innovative curriculum. This is particularly important in small schools where these positions may not exist. Prioritize funding for the development of innovative curriculum on a recurring basis, and prioritize professional development opportunities for teachers seeking to broaden their multicultural integration.

For educators, the results of the research questions reveal a wide disparity in how Black history is taught and reflected within the curriculum. Teachers should encourage open dialogue between administrators, educators, students and parents when creating curriculum. This recommendation is in line with Zeichner and Guillen's work (2018) concerning the need for community involvement in school planning. This shouldn't just be for "approval” of controversial topics, and instead should be a conversation on teaching principles in general. This 
recommendation also aligns with Muhammed's (2021) Historically Responsive Literacy framework encouraging student input, teacher research and parent involvement in building a curriculum.

In cooperation with administration, teachers should create and sustain teacher mentor programs when possible to ease the transition from preservice teacher to career teacher. This type of program encourages collaboration amongst different subject areas as well. Teacher mentor programs are shown to improve teacher acclimation to their classroom and allow teachers the opportunity to reflect on their practices with other veteran teachers (Hill-Harris, 2009; Mathur, Gherke \& Kim, 2012).

For post-secondary educators, specifically "teachers of teachers," or methods instructions should prioritize multicultural teaching within their curriculum. Teaching teachers to be empathetic and inclusive does not have to only happen in the one or two college-mandated multicultural classes - it must happen in the methods courses as well. Colleges and universities should strongly consider bolstering their multicultural course requirements for preservice teachers. This suggestion strongly correlates with Neumann's research (2010) of over 300 American colleges and universities, with less than half required at least one course in multicultural teaching.

\section{Suggestions for Future Research}

Future research concerning the incorporation of Black voices and perspectives into the curriculum requires a much larger sample size from various states. This study only focused on small town, rural educators, but a potential contrast between rural and urban educators deserves to be studied as well. A study including educators from various "red" and "blue" states would also create a wealth of knowledge concerning the politics of teaching. This study produced a 
glimpse into the struggles faced by small town educators who teach in predominantly all-white towns dominated by conservative political ideologies; however, questions persist. What impact will the ever-divisive 2020 election continue to have on public school educators? With a recent pushback on teaching "critical race theory" or any inherently controversial topic, how can preservice, new or even experienced teachers better maneuver this tricky teaching environment? How can districts provide better access to proven resources that open up avenues of learning for students? This study only opens the door to more research that is needed to better understand small town educators and their incorporation of not just Black voices and perspectives, but of all marginalized voices. This needs to be looked at from the state level, to even the national level in order to better understand not just how history is being taught, but what factors are shaping the way it is taught. In order for the social studies to truly be inclusive, meaningful and representative of the vast array of cultural differences present in this country, the curriculum being taught to our students should reflect that diversity.

Along with those persisting questions, more research is necessary concerning the impact gender and political identity has on making curriculum decisions. As noted, patterns emerged showing a strong correlation between gender and higher incorporation of multicultural content.

\section{Conclusion}

Today, more than ever before, social studies teachers face the challenge of "keeping their opinions out of their teaching." In our highly politicized world post-Trump presidency, teachers have been attacked for indoctrinating the youth of America, and teaching "un-patriotic" histories

of this country. This widespread myth even prompted the former Trump Administration to create the "1776 Commission," which included no experts in United States' History. The commission made a recommendation to educators that there must be a "resolve to teach future generations of 
Americans an accurate history of our country so that we all learn and cherish our founding principles once again. We must renew the pride and gratitude we have for this incredible nation that we are blessed to call home" (1776 Commission, 2021, p. 24). Going further, the commission attacked historians such as Howard Zinn and the "1619 Project" itself, saying "they disdain today's students, just as they doubt the humanity, goodness, or benevolence in America's greatest historical figures. They see only weaknesses and failures, teaching students truth is an illusion, that hypocrisy is everywhere, and that power is all that matters" (1776 Commission, 2021, p. 40).

These pressures, whether from the President of the United States, students or community members, take a toll on teachers who simply want their students to become more informed and justice-oriented citizens as the country continues to grapple with its turbulent racial history. This study concluded that teachers in small town districts really are all over the spectrum as it relates to incorporating multicultural content, specifically, Black voices and perspectives into the curriculum. The study revealed that teachers favored the idea of teaching Black voices and perspectives, but varied in their approach to doing so and to what extent. All agreed that this content is beneficial to their students, but some received harsh pushback from students and the community. The findings in this study revealed that even if teachers do want to incorporate Black voices and perspectives, they lacked the necessary resources or even training to do it in an engaging way. When provided with these resources and training, educators unlocked multiple paths in which their curriculum expanded, grew and developed. 


\section{REFERENCES}

Adichie, C. (2009, October 7). The danger of a single story [Video]. TED. https://www.youtube.com/watch?v=D9Ihs241zeg

Alexander, C., \& Weekes-Bernard, D. (2017). History lessons: inequality, diversity and the national curriculum. Race, Ethnicity, and Education, 20(4), 478494. https://doi.org/10.1080/13613324.2017.1294571

Ayalon, A. (1993). Does multicultural education belong in rural White America? Paper presented at the 1993 National Rural Education Association Convention. (ERIC Document Reproduction Service No. 364376).

Banks, J. A. (2015). Cultural diversity and education: Foundations, curriculum, and teaching (6 $6^{\text {th }}$ edition). Routledge.

Banks, J. A., Cookson, P., Gay, G., Hawley, W. D., Irvine, J. J., Nieto, S., \& Stephan, W. G. (2001). Diversity within unity: Essential principles for teaching and learning in a multicultural society. Phi Delta Cappan, 83(3), 196-203. https://doi.org/ $10.1177 / 003172170108300309$

Banks, J, McGee-Banks, C. (2016). Multicultural education: Issues and perspectives (9th edition). Hoboken, New Jersey: John Wiley \& Sons, Inc.

Bar-Tel, D. \& Harel, A. (2002). Teachers as agents of political influence in the Israeli high schools.

Teaching and Teacher Education 18, 121-134.

Beghetto, R. (2019). Taking beautiful risks in education. Educational Leadership 76(4), 18-24.

Braun, V. \& Clarke, V. (2006) Using thematic analysis in psychology. Qualitative Research in Psychology, 3(2), 77-101. https://doi.org/10.1191/1478088706qp063oa 
Busey, C., \& Russell III, W. (2016). "We want to learn": Middle school latino/a students discuss social studies curriculum and pedagogy. RMLE Online: Research in Middle Level Education, 39(4), 1-20. https://doi.org/10.1080/19404476.2016.1155921

Campbell, D. (2007). Sticking together: Classroom diversity and civic education. American Politics Research, 35(1), 57-78. https://doi.org/10.1177/1532673X06294503

Chandler, P. T. (2006). Academic freedom: A teacher's struggle to include "other" voices in history. Social Education, 70(6), 354-357.

Chandler, P. T. (2009). Blinded by the white: Social studies and raceless pedagogies. Journal of Educational Thought 43(3), 259-288.

Cohen, C. (2008). The true colors of the new Jim Toomey. In Lee, E., Menkart, D. \& OkazawaRey, M. (Eds.), Beyond heroes and holidays: A practical guide to $k$-12 anti-racist, multicultural education and staff development (pp. 57-68). Teaching for Change.

College Board. (2020). Reconstruction. In A.P. U.S. Course and Exam Description. College Board.

Collins, J. W., \& O'Brien, N. P. (2011). The greenwood dictionary of education: Second edition. ProQuest Ebook Central https://ebookcentral.proquest.com

Common Core State Standards Initiative. (2020). English language arts standards » history/social studies » grade 11-12. http://www.corestandards.org/ELA-Literacy/RH/11-12/

Duncan, J., Zawistowski, C., \& Luibrand, S. (2020, February 19). Map in widely used U.S. history textbook refers to enslaved Africans as "immigrants," CBS News analysis finds CBS News. https://www.cbsnews.com/news/the-american-pageant-map-in-widely-usedus-history-textbook-refers-to-enslaved-africans-as-immigrants-cbs-news/ 
Duncan, J., Zawistowski, C., \& Luibrand, S. (2020, February 19). 50 states, 50 different ways of teaching America's past. CBS News. https://www.cbsnews.com/news/us-history-howteaching-americas-past-varies-across-the-country/

Dunn, A. H., Sondel, B., \& Baggett, H. C. (2019). “I Don’t Want to Come Off as Pushing an Agenda": How Contexts Shaped Teachers' Pedagogy in the Days After the 2016 U.S. Presidential Election. American Educational Research Journal, 56(2), 444-476. https://doi.org/10.3102/0002831218794892

Epstein, T. (2000). Adolescents' perspectives on racial diversity in U.S. history: Case studies from an urban classroom. American Educational Research Journal, 37(1), 185-214. https://doi.org/10.3102/00028312037001185

Flick, U. (2007). Designing qualitative research. SAGE Publications.

Fullan, M., \& Langworthy, M. (2014). A rich seam: How new pedagogies find deep learning. London: Pearson. Retrieved from http://www.michaelfullan.ca/wp-content/uploads/2014/01/3897.Rich_Seam_web.pdf

Gollnick, D. M. (1995). "National and state initiatives for multicultural education." In Handbook of Research on Multicultural Education, ed. James Banks, \& Cherry A. McGee Banks. New York, NY: Macmillan.

Groenke, S., Haddix, M., Glenn, W., Kirkland, D., Price-Dennis, D., \& Coleman-King, C. (2015). Disrupting and dismantling the dominant vision of youth of color. English Journal, $104(3), 35-40$.

Harris, R., \& Clarke, G. (2011). Embracing diversity in the history curriculum: A study of the challenges facing trainee teachers. Cambridge Journal of Education, 41(2), 159-175. https://doi.org/10.1080/0305764X.2011.572863 
Hannah-Jones, N. (2019). The 1619 Project. The New York Times.

https://www.nytimes.com/interactive/2019/08/14/magazine/1619-america-slavery.html

Hill-Harris, C.L. (2009). The impact of a new teacher mentoring program on teacher

effectiveness.[Doctoral dissertation, Walden University, Minneapolis]. ERIC.

https://eric.ed.gov/?id=ED535192\#: :text=In\%20recent\%20years\%2C\%20research\%20has

\%20demonstrated $\% 20$ that $\% 20$ participation,an\%20improvement $\% 20 \mathrm{in} \% 20$ the $\% 20$ academi c\%20performance\%20of\%20students

Howard, P., Becker, C., Wiebe, S., Carter, M., McLarnon, M., Schuman, L., Gouzouasis, P., Richardson, P., \& Ricketts, K. (2018). Creativity and pedagogical innovation: Exploring teachers' experiences of risk-taking. Journal of Curriculum Studies, 50(6), 850-864. https://doi-org.libproxy.lib.ilstu.edu/10.1080/00220272.2018.1479451

Huckleberry, P., \& Berrey, S. (2021). Something has gone very wrong: The homepage of James W. Loewen. https://sundown.tougaloo.edu/

Illinois State Board of Education. (2017). IL social science standards.

https://www.isbe.net/Documents/K-12-SS-Standards.pdf

Jackson, A. (2019, August 11). LGBTQ history curriculum will now be taught in Illinois schools. CNN. https://www.cnn.com/2019/08/11/us/illinois-lgbtq-history-curriculumtrnd/index.html

Jiménez, J., Lerch, J., \& Bromley, P. (2017). Education for global citizenship and sustainable development in social science textbooks. European Journal of Education 52(4), 460-76.

Jones, M.D. (2015). How do teachers respond to tenure? IZA Journal of Labor Economics 4(8). https://doi.org/10.1186/s40172-015-0024-6 
Kahne, J. (2009). Closing the civic opportunity gap: How schools can promote political equality. Social Studies Review 48(1), 28-31.

Kellogg, L. (2015). States and multicultural education policies: An event history analysis. [Doctoral dissertation, University of Nevada, Las Vegas]. UNLV Theses, Dissertations, Professional Papers, and Capstones.

Kennedy, D., Cohen, L., \& Bailey, T. (2006). The American pageant: A history of the republic (13th ed.). Boston: Houghton Mifflin.

King, N. (2004). Using templates in the thematic analysis of text. In C. Cassell \& G. Symon (Eds.), Essential guide to qualitative methods in organizational research (p. 257-270). London, UK: Sage.

Knott, K. (2020, July 4). New history curriculum created to aid anti-racist teaching. Washington Post. https://www.washingtonpost.com/local/new-history-curriculum-created-to-aid-antiracist-teaching/2020/07/04/241960c2-bdff-11ea-97c1-6cf116ffe26c_story.html

Linneberg, M. \& Korsgaard, S. (2019). Coding qualitative data: A synthesis guiding the novice. Qualitative Research Journal. http://dx.doi.org/10.1108/QRJ-12-2018-0012

Mathur, S. R., Gehrke, R., \& Kim, S. H. (2013). Impact of a teacher mentorship program on mentors' and mentees' perceptions of classroom practices and the mentoring experience. Assessment for Effective Intervention, 38(3), 154-162.

https://doi.org/10.1177/1534508412457873

Maxwell, J. (2013). Qualitative research design: an interactive approach. London, United Kingdom: Sage. 
Michigan Department of Education. (2019). Michigan k-12 standards: Social studies. https://www.michigan.gov/documents/mde/Final_Social_Studies_Standards_Doc ument_655968_7.pdf

Minichiello, V., Aroni, R., Timewell E., Alexander, L. (1990). In-depth interviewing: Researching people. Melbourne, Longman Cheshire.

Miles, M. B., \& Huberman, A. M. (1994). Qualitative data analysis: An expanded sourcebook (2nd ed.). Thousand Oaks, CA: Sage.

Milner, H. (2009). What does teacher education have to do with teaching? Implications for diversity studies. Journal of Teacher Education, 61(1-2), 118-131. https://doi.org/10.1177/0022487109347670

Mitchell, B. M., \& Salisbury, R. E. (2000). Multicultural education in the US: A Guide to Policies and Programs in the 50 States. Westport: Greenwood Press.

Muhammad, G., \& Love, B. (2021). Cultivating genius: an equity framework for culturally and historically responsive literacy. Scholastic Inc.

Neubauer, B., Witkop, C. \& Varpio, L. (2019). How phenomenology can help us learn from the experiences of others. Perspectives on Medical Education 8, 90-97.

Neumann, R. (2010). Social foundations and multicultural education course requirements in teacher preparation programs in the United States. Educational Foundations, Summer-Fall, $3-17$.

New Visions for Public Schools. (2021). New Visions Social Studies Curriculum. https://curriculum.newvisions.org/social-studies 
Nieto, S. (2008). Affirmation, solidarity and critique: Moving beyond tolerance in education. In Lee, E., Menkart, D. \& Okazawa-Rey, M. (Eds.), Beyond heroes and holidays: A practical guide to k-12 anti-racist, multicultural education and staff development (pp.18-29). Teaching for Change.

Olson, B. (2003). Attitudes toward multiculturalism and cultural diversity: The effects of multicultural training. Unpublished master's thesis, The University of Wisconsin-Stout, Menomonie, Wisconsin.

Paris, D. (2012). Culturally sustaining pedagogy: A needed change in stance, terminology, and practice. Educational Researcher, 41(3), 93-97. https://doi.org/10.3102/0013189X12441244

Popham, W.J. (2014). Classroom assessment: What teachers need to know (7th edition). Pearson.

The President's Advisory 1776 Council. (2021). The 1776 Report.

Queirós, A., Faria, D. \& Almeida, F. (2017). Strengths and limitations of qualitative and quantitative research methods. European Journal of Education Studies, 3(9), 369-387. http://dx.doi.org/10.5281/zenodo.887089

Rogers, J., Franke, M. Yun, J.E., Ishimoto, M., Diera, C., Geller, R., Berryman, A., Brenes, T. (2017). Teaching and learning in the age of Trump: Increasing stress and hostility in America's high schools. Los Angeles, CA: UCLA's Institute for Democracy, Education, and Access.

Saldaña, J. (2015). The coding manual for qualitative researchers. Thousand Oaks, CA: Sage. 
Sciame-Giesecke, S., Roden, D., \& Parkison, K. (2009). Infusing diversity into the curriculum: What are faculty members actually doing? Journal of Diversity in Higher Education, 2(3), 156-165. https://doi.org/10.1037/a0016042

Stanford History Education Group. (2021). History of SHEG. https://sheg.stanford.edu/about/history-sheg University of Washington. (2012). Multicultural Education. University of Washington College of Education.

Warren, M. (2005). Communities and schools: A new view of urban education reform. Harvard Educational Review, 73(2), 133-173.

Washington, E., \& Humphries, E. (2011). A social studies teacher's sense making of controversial issues discussions of race in a predominantly white, rural high school classroom. Theory \& Research in Social Education, 39(1), 92-114. https://doi.org/10.1080/00933104.2011.10473448

Wood, T. D. (2012). Teacher perceptions of gender-based differences among elementary school teachers. International Electronic Journal of Elementary Education, 4(2), 317-345. https://files.eric.ed.gov/fulltext/EJ1070480.pdf

Yeo, F. (1999). The barriers of diversity: Multicultural education and rural schools. Multicultural Education, 7(1), 2-7.

Yin, R. (2017). Qualitative research from start to finish (2nd ed.). Guilford Press.

Zeichner, K. \& Guillen, L. (2018). A university-community partnership in teacher education from the perspectives of community-based teacher educators. Journal of Teacher Education 69(2), 140-153. https://doi.org/10.1177\%2F0022487117751133 